\title{
The Determinants of the Volatility of Non-Performing Loans of Tunisian Banks: Revolution Versus COVID-19
}

\author{
Syrine Ben Romdhane ${ }^{1, *}$ and Khaoula Kenzari ${ }^{2}$
}

\author{
${ }^{I}$ Department of Finance and Accounting, High Institute of Management, University of Tunis, Tunisia. \\ ${ }^{2}$ Department of Economics, Faculty of Economics and Management of Tunis, University of Tunis EL MANAR.
}

\begin{abstract}
The paper presents the use of the difference GMM, the system GMM and the Panel VAR for the purpose of determining the critical determinants of non-performing loans. The aim of the paper is to point out the factors that explain the volatility of NPLs in a time of crisis. The study focused on a sample of 18 Tunisian banks observed during the period 2008-2018. The paper seeks to identify the impact of crucial macro, microeconomic and governance variables on the NPLs. The results suggest that the deterioration in asset quality can be attributed to both macroeconomic and bank-specific factors. The liquidity risk has a positive and significant correlation with the NPLs of Tunisian banks. The variable "Revolution" presents a positive though not significant relationship with these. Also, the results emphasize the strength of macrofinancial feedback loops in Tunisia. As for the effect of the positive shock of the revolution on the NPL level, we note that it is significant and negative. The decomposition of the sample into two sub-samples: pre-revolution period and post-revolution period allowed showing that the ROA and the ownership structure affect negatively and significantly the NPLs of the banks in the two periods, while the capital affects them positively. It appears that bank-specific factors explain well the volatility of NPLs, especially in the post-revolution period. Finally, by a descriptive study, we have shown that the COVID-19 crisis explains the volatility of the NPLs of Tunisian banks.
\end{abstract}

Keywords: Non-performing loans, dynamic panel, panel VAR, revolution, COVID-19.

\section{INTRODUCTION}

Understanding the determinants of Non-Performing Loans (NPLs) is a matter of critical importance for the stability of the macroeconomic and financial system. A large number of studies have examined credit risk factors, particularly in the period following the onset of the global economic crisis. Some studies have used a single category of potential determinants, while others have focused on the interaction between systemic factors (such as, general macroeconomic conditions) and idiosyncratic influences (like bank-specific variables or company information). Reinhart and Rogoff (2010) indicate that NPLs can be used to mark the beginning of a banking crisis.

The deterioration in the quality of banks' assets is not only destabilizing for the banking system, but it can also reduce economic efficiency and prosperity. Barseghyan (2010) measured the effects of the reduction in economic activity in Japan during the "lost decade" of the 1990s. His analysis shows that, in a general equilibrium framework characterized by a delay in putting in place a government-led bailout, the NPLs cause a decline in economic activity by crowding out funds that might otherwise be used for productive invest-

*Address correspondence to this author at Department of Finance and Accounting, High Institute of Management, University of Tunis, Tunisia, E-mail: syrine_br@yahoo.fr ments. Other authors qualify NPLs as "financial contamination" because of their negative economic impact (Barseghyan 2010, Gonzalez-Hermosillo 1999, Zeng 2012).

As for 2011, the Tunisian Revolution opened up promising prospects for the country in terms of economic and social development. The establishment of democracy, freedom and good governance organizes the release of initiatives, the encouragement of domestic and foreign investment and the growth of economic activity. But, the economic growth has experienced a potential stagnation in 2011 which resulted in worsening unemployment and expanded needs for external resources to be mobilized to fulfill the deficit in the state budget. This has not improved with the attempts the country has experienced in recent years. The country's political instability and the insecurity of neighboring countries (Algeria, Libya) have also weakened the system. Other troubles, existing before 2011, have also amplified since, worsening the situation, such as the rise of informal economy, smuggling, the democratization of corruption and terrorism.

The banking system is dragging high rates of NPLs with banks in the development phase of new products and services (remote access, Smartphone application). The banking system faces considerable difficulties due to undercapitalization, poor asset quality and insufficient funds made to cover the risk of default. There is also no doubt that the phenomenon of NPLs is massive and pivotal in Tunisia since 
it fluctuates depending on the period and the source from $20 \%$ up to $40 \%$ knowing that the international standard establishes bank commitments at $2 \%$. In addition, bank deposit withdrawals have reached a high level, forcing the sector to assume a great need for liquidity. Indeed, since the revolution individuals as well as companies have preferred to keep cash instead of investing or leaving money in their current accounts. These results condemn the stability of both the financial system in general and the Tunisian banking system in particular after the revolution.

On the other hand, today we are witnessing economic upheavals that could be more serious than those we experienced during the Tunisian Revolution. The coronavirus pandemic is a different kind of a shock in a way that modern economy has never before experienced such a sharp halt in costs. The strains on the banking system are growing and more serious defaults are imminent. Many therefore expect a shock to the financial sector of a magnitude equivalent to that of the 2008 crisis. It would then be appropriate to wonder about the impact of COVID-19, a new crisis which intensifies the instability of the financial system, on NPLs. This crisis manifests in lower demand, lower fund transfers, rising unemployment, decrease in consumption, interest rate fluctuation and depreciation of currencies. The financial and real economy is directly impacted and generates additional risk exposure that banks have to deal with. The COVID-19 crisis we are experiencing resubmitted this topic in the middle of the financial system.

In this research paper, we will attempt to analyze the factors that explain the volatility of NPLs of Tunisian banks. For this purpose, four parts will be presented: the first will study the determinants of NPLs by integrating macroeconomic, microeconomic and governance variables by carrying out an empirical analysis of the relationship a relevant econometric model can exert in order to demonstrate the feedback between the financial system and NPLs. The second part will focus on the impact of the 2011 Tunisian Revolution, as a measure of the instability of the financial system, on NPLs of Tunisian banks. The third part explores the feedback effects of the banking sector on the real economy. Finally the fourth part will be devoted to discuss the impact of financial system instability measured by COVID-19 on NPLs. The goal of these parts is to determine the factor of the instability of the financial system that affects the NPLs of Tunisian banks.

\section{MACRO, MICROECONOMIC AND GOVERNANCE FACTORS EXPLAINING THE VOLATILITY OF NPLS}

\subsection{Theoretical Literature Review}

Studies aimed at explaining bank failures indicate that defaulting credit institutions tend to have large amounts of problem loans and that asset quality is a statistically significant predictor of insolvency (Berger and De Young, 1997). The literature examining credit risk drives describes several important categories of potential determinants, ranging from macroeconomic and institutional factors to bank-specific variables and company-level information.
Models examining the influence of macroeconomic factors on credit risk focus primarily on the relationship between the economic cycle and the ability of mortgagors to service their loans. The central idea behind these studies is that credit standards gradually deteriorate during economic expansions, as lending institutions apply increasingly liberal lending policies in their quest for market share (see, for example, Keeton 1999 and Fernandez De Lis et al. 2000). These policies may take the form of "negative NPV" strategies, involving reduced interest charges and / or increased lending to lowcredit borrowers (Rajan, 1994). Such strategies usually backfire during times of recession, when credit risks actually materialize. Recent studies examining the role of the business cycle in the evolution of credit risk include, for example, Borio et al. (2001), Quagliariello (2007) and Beck et al. (2013).

Studies examining the effect of borrowing strategies use bank-specific information as descriptive variables in models that analyze the progression of bad debts and other measures of ex-post credit risk. Some of the literature considers company-specific information for the idiosyncratic component of credit risk. Related studies focus on a number of accounting data as likely determinants of bad debts and other indicators of corporate credit risk. These factors are, for example, the company's sales growth, profitability, cost of financing, leverage, asset growth, size and age (Bunn and Redwood, 2003).

Another study flow examines the possible effect of the business and regulatory environment on the amount of problem loans on bank balance sheets. These studies examine the importance of various indicators of the quality and stability of a country's legal, regulatory, institutional and political environment. Relevant measures include the degree of information sharing between creditors and borrowers, the legal rights of borrowers and lenders (as reflected, for example, by the presence or absence of a strong bankruptcy framework) as well as the degree of control of corruption. Studies examining the impact of these regulatory and institutional factors include, for example, La Porta et al. (1997), Jappelli and Pagano (2002), Godlewski (2004) and Djankov et al. (2007).

More recently, a growing number of studies estimate models that combine the above categories of variables to explain the evolution of credit risk. For example, Quagliariello (2007) combines macroeconomic and bank-specific determinants to study the degree of risk (as represented by the evolution of loan loss provisions and the flow of new impaired loans) of a large database of Italian intermediaries over the period 19852002. In the same vein, Louzis et al. (2012) use a balanced panel composed of surveillance data from the nine largest Greek commercial banks to test a number of hypotheses and explain the intertemporal evolution of NPLs in Greece over the period starting from the first quarter of 2003 to the third quarter of 2009. Separately, Belaid (2014) combines macroeconomic and bank-specific variables with a data set containing information for more than 9,000 domestic companies to explain the determinants of loan quality in the Tunisian banking sector over the period 2001-2010.

Finally, Boudriga et al. (2009) empirically analyzes the determinants of NPLs and the potential impact of the business and institutional environment on the credit risk exposure of 
banks in the MENA region. By examining a sample of 46 banks in 12 countries over the period 2002-2006, they found that the credit quality of banks is positively affected by the relevance and quality of credit information published by public and private offices. Their findings also underscore the importance of a healthy institutional environment for improving credit quality of banks. According to their analysis, better control of corruption, good regulatory quality, better application of the rule of law, freedom of expression and accountability play an important role in reducing bad debts in MENA region countries.

\subsection{Review of Empirical Literature}

Researchers have found a link between macroeconomic determinants and loan quality, which is a crucial criterion for the prosperity of the banking sector. Indeed, Keeton and Morris (1987) examined the losses of 2,470 commercial banks in the United States (US) between 1979 and 1985. Using loan losses net of charges as the primary measure of loan losses, the authors show that local economic conditions as well as the poor performance of certain sectors explain the variation in loan losses recorded by banks. The authors also note that commercial banks with great risk propensity tend to experience higher losses. In addition, Ozili (2019) attempted to address the issue of the interaction between NPLs and the stage of the business cycle. Knowing that, structural differences between countries can create differences in the efficiency of banks as well (Liu, 2019).

Skarica (2014) found that the main sources of NPL are economic slowdown (GDP), lack of employment and inflation rate. A study conducted in France and Germany showed that macroeconomic variables influence NPLs (Chaibi and Ftiti, 2015). The researchers also found that the French economy is more vulnerable than Germany to specific bank factors. Economic expansion and unemployment are positively associated with the reduction of NPLs. Macroeconomic variables, including unemployment and economic development, significantly influence NPLs, while industry-specific variables, such as management skills and risk preferences, have implications for future NPLs (Dimitrios, Helen and Mike 2016).

Vardar and Özgüler (2015) found the presence of a consistent and long-term affiliation between NPLs, macroeconomic variables and bank-specific factors. Inflation and unemployment have been shown to be positively and significantly associated with NPLs. Bardhan and Mukherjee (2016) found results supporting the mismanagement hypothesis predicting negative future relationships with non-performing assets. They used performance as an indicator of management effectiveness. According to their research, large banks have a higher default rate than small ones.

Makri, Tsagkanos and Bellas (2014) and Radivojevic and Jovovic (2017) report that ROA (Return on Assets) and ROE (Return on Equity) are the most important indicators of efficiency and profitability, i.e. of the quality of management banking, but they found that these factors have a different impact than NPLs. Godlewski (2005), Radivojevic and Jovovic (2017) found that there is a negative impact and a significant correlation between these factors and NPLs, while Garsiya and Fernandez (2007) and Boudriga et al.
(2009) identified a positive relationship between these factors and NPLs. It's the same for other macro and micro factors of NPLs, such as unemployment rate, interest rate, exchange rate, market capitalization, bank size, etc.

Owojori, Akintoye, and Adidu (2011) have stated that there are legislative gaps in the financial system, especially in the banking system, which are effective, as well as a lack of equal sharing of credit information among banks. Most of the research focuses on the determinants of NPLs on aggregated data from banking systems (De Bock and Demyanets, 2012; Jakubík and Reininger, 2013; Klein, 2013; Skarica, 2014; Tanasković and Jandrić, 2015). They find that GDP growth has remained the main determinant of NPLs decreasing its level, while the exchange rate, unemployment and inflation increase the level of NPLs. Indeed, interest rates and unemployment are important macroeconomic determinants. Among the characteristics of banks, only the size of the bank is significant and it decreases the credit risk.

Baboucek and Jancar (2005), Rinaldi and Sanchis-Arellano (2006), Nkusu (2011), Mileris (2012), Figlewski, Frydman and Liang (2012) and Radivojevic and Jovovic (2017) have studied the influence of macroeconomic factors on NPL and found that they positively affect NPL. Jovovic (2014) and Shu (2002) reported controversial results, while results from the study by Skarica (2014) shows that this factor has no impact on NPLs. Similar examples can be found in the study of other variables .In addition, Skarica (2014) reported an insignificant dependence between NPLs ratio and the interest rate. On the other hand, Rajan and Dahl (2003), Hoggarth et al. (2005), Saurina and Jiménez (2006) underline that there is a strong correlation between the interest rate and the exchange rate. The results obtained by De Bock and Demyanets (2012) imply that the exchange rate is one of the main determinants of NPLs, contrary to the finding of Klein (2013) that the exchange rate has no significant impact on NPLs. Interestingly, researchers like Salas and Saurina (2002) and Angelini, Bofondi and Zingales (2017) agree on the impact of GDP on NPLs. All reported a statistically significant and negative impact of this macro-factor on the occurrence and movement of NPLs. It is also interesting to note that the authors themselves presented different results when used by different estimators.

Greenidge and Grosvenor (2010) attempted to use univariate autoregressive integrated moving average (ARIMA) and multivariate autoregressive distributed delay models (ARDL) to estimate the aggregate ratio of banking sector NPLs as well as the NPL ratio of different commercial banks of Barbados, for the period 1996-2008. Their empirical results support the idea that macroeconomic factors, such as real GDP growth and the rate of inflation, have an impact on the level of NPLs. In addition, bank-specific variables, growth in total loans, and relative market share appear to have explanatory power for NPLs.

Salas and Saurina (2002) use a dynamic model and a panel dataset covering the period between 1985-1997 to study the determinants of problem loans from Spanish commercial banks and savings banks, and find that real GDP growth , rapid credit expansion, bank size, capital ratio and market power explain the variation in NPLs. The same goes for other authors such as $\mathrm{Hu}, \mathrm{Li}$ and Chiu (2004) who analyze the 
relationship between NPLs and the ownership structure of commercial banks in Taiwan using a panel of data covering the period 1996-1999. The study shows that banks with more public sector ownership recorded fewer NPLs. The authors also show that bank size is negatively related to NPLs, while diversification may not be a determining factor.

Empirical studies examining the determinants of NPLs in the Greek banking system are limited to the study by Louzis, Vouldis and Metaxas (2012), where the authors focus on the effects of bank-specific variables on NPLs. This study examines the determinants of NPLs, in case there is always the risk that endogeneity issues could affect the results. The authors use panel data method to examine the determinants of NPLs in the Greek banking sector, which does not take into account the increased dynamic interdependencies between different variables. The results show that bad loans are linked to certain macroeconomic variables and to the quality of management.

Makri, Tsaganos and Bellas (2014) attempted to identify, using an econometric model, the factors affecting the NPL rate of banking systems in the euro area for the period 20002008. By examining macroeconomic variables (annual growth rate as a percentage of GDP, debt as a percentage of GDP, unemployment rate) and microeconomic variables (loans on deposits, return on assets, return on equity), they sought to know which of these elements significantly affect NPLs rate. Their findings reveal strong correlations between NPLs and various macroeconomic (public debt, unemployment, annual growth rate as a percentage of GDP) and bankspecific (capital adequacy ratio, NPL rate of the previous year and return on equity).

Abid, Ouertani and Ghorbel (2014) tried to study the macroeconomic and microeconomic determinants explaining the NPL of households in Tunisia. They found that, over the past ten years, the demand for credit in its various forms has grown exponentially leading to a high level of overindebtedness and a real risk of destabilization. The empirical validation of their article is made from a sample of sixteen Tunisian banks observed over the period from the first quarter of 2003 to the fourth quarter of 2012. The estimation of a dynamic panel model by the generalized moment's method (GMM) found that macroeconomic factors, such as economic growth, the level of inflation, and microeconomic factors, such as management quality play a significant role in the increase in bad debts of households in Tunisia.

El Ansari and Ben Abdallah (2017) tried to determine the main determining factors of NPLs for a sample made up of eight main Moroccan banks for the period from 2005 to 2015. The explanatory variables used are of two categories: macroeconomic and bank specific. The specific variables taken into account in their model are the profitability of assets, the cost / income ratio, the change in granted credit and the average debit interest rate. As for macroeconomic variables, the choice fell on the GDP growth rate, the growth of agricultural added value, the unemployment rate and the inflation rate. The application of the panel data method made it possible to conclude that NPLs vary negatively with the GDP growth rate, agricultural GDP growth and the profitability of bank assets, and positively with the unemployment rate, the inflation rate and the average borrowing rate and the banks' cost / income ratio.

Radivojević et al. (2019) used the GMM method to identify an econometric model to demonstrate the impact of macro and micro economic variables on the NPLs of emerging markets in Latin American countries. They showed the insignificance of the impact of inflation, the interest rate and microeconomic variables on NPLs.

\subsection{Definition of Variables}

In recent years, several authors have been interested in the issue of NPLs and have designed more or less complex econometric models on this subject to understand and determine the causes of the instability of these NPLs. For this research, we considered a database composed of variables whose choice was guided by recent studies on the determinants of NPLs. These variables are essentially the same as those used by Skrabic Peric et al. (2018), Radivojevic et al. (2019), Abid, Ouertani and Ghorbel (2014) and Tanaskovic and Jandric (2015), our main benchmarks.

\subsubsection{The Dependent Variable}

To analyze the factors explaining the volatility of nonperforming bank loans, we introduce the NPL variable measuring the cost of credit risk. This is the litigation rate calculated by the ratio of overdue debts to total loans. Credit risk manifests itself in a high rate of NPLs. The latter is one of the financial stability indicators on which the IMF (International Monetary Fund) and the WB (World Bank) are based to assess the fragility of financial sectors.

\subsubsection{The Independent Variables}

Sinkey and Greenawalt (1991), Kwan and Eisenbeis (1995), as well as Salas and Saurina (2002) have dealt with the determinants of NPLs at the level of American and Spanish banks with particular focus on macroeconomic determinants. These authors have shown that the accumulation of NPLs does not depend only on macroeconomic factors, but also on banks financial conditions. A second set of factors identified as determinants relates to external events, such as the overall macroeconomic conditions that may affect the ability of borrowers to repay their loans.

In addition, other research (Demirguç-Kunt and Detragiache 1998, La Porta et al. 1997 and Acclassato, Ali Aga and Eggoh 2009) has emphasized the strong effect of corruption, as an indicator of governance, on banks' NPLs. Corruption is a hallmark of failing legal and institutional systems. It increases the uncertainty of banks and the inability to recover loaned funds in case of bankruptcy. Bank officials can compromise with high risk factors associated with a loan proposal, resulting in bad loan (Chen et al. 2015). The contribution of our research is that we will consider a third set of factors emphasizing corruption as a factor influencing the volatility of NPLs.

\section{MACROECONOMIC FACTORS}

The first macroeconomic determinant of NPLs cited by the literature is the unemployment rate. The work of Louzis et al. (2012) show that low-income borrowers have very high 
default probabilities because of the potential risk of unemployment rendering them unable to honor their commitments. Thus, the unemployment rate is positively related to the NPLs. A rise in the unemployment rate can subsequently negatively influence the purchasing power of households, and consequently increase their debt charges. This finding is consistent with the conclusions of Louzis et al. (2012) for the case of Greek banks and Bofondi and Ropele (2011) for Italian banks. This situation can have the same effect for businesses. Indeed, when the activities of firms decrease, they can no longer honor their commitments to banks.

The negative relationship between real GDP growth and NPLs has been addressed by several empirical studies. Caprio and Kingebiel (2003) have held that the decline in the level of production and consequently in economic growth puts borrowers at risk. This result was found by Nkusu (2011) who showed that a slowdown in the economy contributes to increasing the stock of NPLs. Likewise, the study by De Bock and Demyanets (2012) corroborates these findings and concludes that an improvement in the real economy is likely to see a reduction in NPL portfolios. Therefore, real GDP growth has a negative effect on the volume of NPLs.

The work of Jakubík and Reininger (2013) looked at the case of Central and Eastern European banks over a period from 2004-2012 in quarterly data. They concluded that in addition to real GDP growth, there is a significant positive relationship between the real effective exchange rate and NPLs. These results are in line with research carried out by Dash and Kabra (2010) on the sensitivity of Indian banks' NPLs to economic factors, including the real effective exchange rate.

Similarly, the impact of the inflation rate on NPLs has been widely discussed in the literature. According to Klein (2013), the effect of inflation can be ambiguous. A high level of inflation can affect NPLs, and subsequently disturb the stability of the banking system because an increase in the price level lowers the real income of households, if their wages are rigid. The increase in the level of inflation rates can also lead to an increase in the volume of NPLs and consequently affect bank solvency. This is justified by the fact that the rise in the price level leads to a reduction in the purchasing power of households, if wages are inflexible. For example, a large portion of households may not be able to honor their debts to the bank, due to increased inflation. Indeed, in case the inflation is volatile, the proper assessment of credit risk becomes more difficult. On the other hand, a drastic and rapid fall in the inflation rate can lead to a fall in nominal income, which negatively affects liquidity and solvency. However, in the short term, the inflation rate does not have a significant impact on NPLs (Asari et al., 2011).

Similarly, the impact of real interest rates on NPLs is widely discussed in the literature, as they affect the volume of NPLs when loans are granted at variable rates (Bofondi and Ropele, 2011). Therefore, a positive relationship between the real interest rate and NPL volume can took place.

\section{THE GOVERNANCE INDICATOR (CORRUPTION)}

Acclassato, Ali Aga and Eggoh (2009) present a review of the literature on the relationship between corruption and NPLs by isolating different axes:
The first axis is that of La Porta et al. (1997, 1998). It shows the negative impact of corruption on non-performing bank loans through the relationship between the legal framework and corruption. Indeed, a transparent legal system reduces corruption and therefore allows credit growth and better efficiency of banks and greater credit risk. Indeed, in case of bankruptcy of the borrower, the bank is protected by law. It can either collect the funds or take possession of the company. If there is corruption, this protection can be greatly reduced and the functioning of the system crippled.

The second axis is beyond the quality of the legal system. It highlights the complicity that may exist between the lender and the borrower. The first can overestimate the profitability of the project. As for the second, corruption leads him to make little effort to achieve the best profitability of the project. Also, appears another negative effect of corruption on bank lending, and therefore a negative effect on NPLs: it is not the most profitable project that will be financed but that of the most corrupt entrepreneur. Beck, Demirguç-kunt and Levine (2005) test the correlation between the nature of banking supervision and the level of corruption in an economy. These authors find that, in countries with strong banking supervision, firms have more difficulty in obtaining credit because of the corrupt behavior of bankers. In this context, the article by Demirçu-kunt and Detragiache (2000) revealed the negative impact of insurance on deposits in an institutional environment characterized by a high presence of corruption.

The third axis can be found in the work of Ahlin and Pan (2008). They carry out a macroeconomic study which assesses, in the same growth equation, the impact of financial development and corruption. Their results show substitutability between corruption and financial development. Indeed, a low level of corruption favors productive investment despite a weakness in financial development.

Weill (2009) describes the effect of corruption on bank lending in Russia and shows that the negative effects are mainly on household and corporate borrowers. Corruption could unexpectedly improve bank lending. Indeed, the fact that the adverse selection leads to a restriction of the credit granted, corruption by facilitating a lubrication of the mechanism increases the quantity of loan granted and thereby improves the flexibility of the process of granting the bank loan, which will generate greater credit risk and therefore more NPLs likely. In our study, a positive sign between corruption and NPLs is expected.

\section{SPECIFIC FACTORS OF BANKS}

In addition to macroeconomic variables, the distinctive characteristics of credit institutions and the strategic choices of each bank exert a decisive influence on the increase in the NPLs portfolio. Among the bank-specific factors most cited in the literature: the size, the degree of sector concentration of the customer portfolio, the financial conditions of credit (maturity, interest rate and type of rate), the bank's profitability, business efficiency and profit margins.

The size of the banking institution is measured by the natural logarithm of the bank's total assets, and the expected sign of this variable is positive/negative (+/-). Large banks generally 
cooperate with large companies and have more transparent customer relationships. They have better risk management strategies. They have a larger loan portfolio than small banks. Thus, one could predict a negative relationship between the size variable and the NPLs. However, senior banks can increase their risky loans because they will be protected by the state in case of bankruptcy ("too big to fail"). In previous research on NPLs, the results are mixed. While Agora$\mathrm{ki}$ et al. (2011) find a negative relationship between the size of the bank and the NPLs, Louzis, Vouldis and Metaxas (2012) rather find a positive relationship between these two variables. Hu et al. (2004) state that large banks have more resources and are more experienced in dealing better with bad borrowers. Small banks, on the other hand, can be exposed to the problem of adverse selection due to the lack of skills and experience necessary to effectively assess the credit quality of borrowers. In other words, and according to $\mathrm{Hu}$, $\mathrm{Li}$ and Chiu (2004), large banks have the necessary resources to properly assess credit applications and improve the quality of their portfolios. Consequently, the rate of NPLs is lower in senior banks than in small ones. This result was confirmed by Anderson and Fraser (2000) and invalidated by GarciaMarco and Robles-Fernandez (2008). They note that the bigger the bank, the more managers are motivated to undertake less careful and more complex policies.

ROE and ROA are two ratios that are used as conventional measures of banking performance. In addition, they are also used in the literature as a proxy for the quality of bank management. The study of profitability in terms of flow ensures that the sustainability of benefits and severity of risks incurred are taken into account. Poor risk management is one of the sources of the bad debt allowance ratio. It corresponds to a slight assessment of loan projects and / or a collateral lack of borrower control. According to studies by Seuraj and Watson (2012), Louzis, Vouldis and Metaxas (2012), bank profitability has a negative effect on NPLs. This observation was confirmed by Godlewski (2004) who showed that the repercussions of bank profitability are negative on the level of NPLs ratio. Kolapo, Ayendi and Oke (2012) studied the relationship between the performance of the bank and the management of credit risk. Their result shows that profitability as measured by ROA negatively affects the NPLs of financial institutions. Makri et al. (2014) showed that there is a negative affiliation between ROA and NPL, while Ahmad (2003) stated that there is a positive association between these. Kirui (2014) stated that the impact of NPLs on the profitability of commercial banks in Kenya was negative, and NPLs reduced bank profitability from 2004 to 2013. Dimitrios et al. (2016) studied the different determinants of NPLs in the euro banking system and concluded that ROAs have a significant impact on NPLs. Rachman et al. (2018) examined various banking factors that affected NPLs in Indonesia and concluded that the high profitability of banks has lower NPLs due to their better progression activity and efficient credit monitoring system. Kumar and Kishore (2019) studied various banking and microeconomic factors as elements of NPLs in the UAE banking system (United Arab Emirates) and found that ROA has insignificant association with NPLs. Kumar and Kishore (2019) argued in their study that NPLs and ROA have a negative association in the banking industry. Koju et al. (2018) conducted a study on
Nepal's banking sector and concluded that ROA has a negative relationship with NPL.

Makri, Tsagkanos and Bellas (2014) have emphasized the relationship between the "FUNDING" variable and NPLs. Bank financing is measured by total loans divided by total deposits. This ratio indicates bank liquidity by measuring the funds banks use to lend from collected deposits. Banks that are less dependent on deposits are more oriented towards external sources of funding, and therefore, the transfer of risk from the internal capital market would be more visible. This is how the expected sign is positive.

Also, to control the differences, in terms of credit risk, relating to the capital structure of the bank, we take into account the "CAPITAL" variable which is equal to the ratio of shareholders' equity to the total assets of the bank. The expected sign can be positive or negative (+/-). Iannotta et al. (2007) and Pathan (2009) also used this variable in their research. The bank's capital can influence its management risk. Such high level of capital is to limit the likelihood the bank will act in a less careful way when granting loans. High capital induces large losses for shareholders in case of bank failure (Repullo, 2004). According to Dell'Ariccia et al. (2013), heavily capitalized banks in the United States are more risky during a period of declining FED interest rates. Makri et al. (2014) also stated that there is a negative association between capital and NPLs.

In addition, there are several studies that are interested at banking risks and foreign ownership of banks (Anginer et al., 2017; Ashraf and Arshad, 2017). De Nicolo and Loukoianova (2007) studied the relationship between banking risk and market structure, and found that ownership is an important variable in risk modeling in emerging countries. In addition, they found that foreign banks take more risk than domestic private banks. Drakos et al. (2016) examined the impact of interest rates in EEC (European Economic Community) countries on banks' risk-taking and found that risk-taking by foreign banks is the higher as interest rates fall during the post-2000 period. According to their results, the decrease in interest rates does not influence risk-taking by national banks. Levine (1996) supports foreign participation which leads to improved financial services and easier access to international financial markets. The foreign presence could improve the attractiveness of the country to foreign direct investment (Brealey and Kaplanis, 1996). Micco et al. (2004) compare the performance of national public banks with domestic private banks and those with foreign capital. They found that in developing countries, public banks underperform their private sector counterparts in terms of bond quality ratio and profitability. They also conclude that this finding is not valid for banks in industrialized countries. We predict a negative relationship between the variable "ownership structure" and the NPLs of banks.

Table (1) defines the different variables retained in our study, presents the corresponding sources and specifies the expected signs:

\subsection{Empirical Estimation Methodology}

To estimate the proposed model, it would be necessary to define the appropriate methodology. NPLs are a dynamic 
Table 1. Definition of Variables and Data Sources.

\begin{tabular}{|c|c|c|c|}
\hline Variables & Definition & Sources & Expected sign \\
\hline \multicolumn{3}{|c|}{ The independent variables } & \\
\hline $\begin{array}{ll}\text { Bank specific indicators } \\
\text { - } & \text { Size (SIZE) } \\
\text { - } & \text { Funding (FIN) } \\
\text { - } & \text { Capital (CAPITAL) } \\
\text { - } & \text { Profitability (ROA) } \\
\text { - } & \text { Ownership (OWNER) }\end{array}$ & $\begin{array}{l}\text { - } \\
\text { - } \\
\text { - } \\
\text { - } \\
\text { Equal loaral logarithm / Tot total assets (in TD) } \\
\text { - } \\
\text { ROA: Net income / Total assets (in \%) } \\
\text { Dummy variable which takes the value } 1 \text { in year } \mathrm{t} \text { if the bank is pre- } \\
\text { dominantly foreign, } 0 \text { otherwise. }\end{array}$ & $\begin{array}{l}\text { RAB } \\
\text { RAB } \\
\text { RAB } \\
\text { RAB }\end{array}$ & $\begin{array}{l}+/- \\
+ \\
+/- \\
- \\
-\end{array}$ \\
\hline
\end{tabular}

$\mathrm{BCT}=$ Central Bank of Tunisia, $\mathrm{RAB}=$ Annual Reports of Banking Activities, WDI $=$ World Development Indicators, WGI $=$ World Governance Indicators

phenomenon, and recent research findings on NPLs confirm that their past value has an impact on their current value (Skrabic Peric et al. 2018; Radivojevic et al. 2019, Abid, Ouertani and Ghorbel, 2014; Tanaskovic and Jandric, 2015). Thus, it would be obvious to use dynamic panel data estimators. Our model will be estimated with the lags of the endogenous variable. Thus, the estimated dynamic equations take the following form:

$N P_{L i} t=\sum \varphi_{m} N P L_{i, t-1}+\beta X^{k}{ }_{t}+\delta Y^{k}{ }_{t}+\mu_{i}+\rho_{i t}$

$\mathrm{Xkt}$ is the vector of the control variables that we are going to define. $N P L_{i, t-1}$ is the lagged endogenous variable. We also assume that the absolute value of the sum of the parameters $\varphi \mathrm{m}$ is lower than the unit and that $\rho_{i t}$ is the zero expectation error term with $\mathrm{E}\left(\rho_{i t} 2\right)=\sigma \rho 2$ variance. Moreover, these stochastic disturbances are independent of the specific effects ( $\mu$ i) and are not correlated when taken in pairs. However, the presence of a lagged variable makes the usual estimation techniques on panel data inappropriate. This is due to the correlation between the endogenous variable and the residuals from the regression. To overcome this problem, the method of instrumental variables applied to the first difference model (in order to eliminate individual fixed effects) allows endogeneity to be taken into account by the use of lagged explanatory variables as instruments.

The equation presented above is a dynamic model insofar as the lagged dependent variable is one of the explanatory variables. The appropriate econometric technique in this case is the generalized method of moments (GMM). It makes it possible not only to provide solutions to endogeneity biases but also to control specific individual and temporal effects. We distinguish two approaches to estimate the empirical model: The first difference GMM estimator of Arellano and Bond (1991) and the system GMM estimator of Blundell and Bond (1998).

Indeed, Arellano and Bond (1991) proposed a procedure of estimations by the GMM in order to improve the efficiency of the method proposed by Anderson and Hsiao (1981) and which proved to produce estimators that are consistent but not necessarily efficient. This procedure contains two steps. First, it is necessary to rewrite the dynamic model in first differences in order to eliminate the specific effects $(\mu \mathrm{i})$, and as a second step, this equation is estimated according to the GMM method by adopting a set of instrumental variables. The vector of instrumental variables is composed of all lagged values of the endogenous variable. 
When the explanatory variables and the dependent variable are strongly persistent, Blundell and Bond (2000) show that the instruments used for the difference GMM (DGMM) estimator are weak and that this estimator is not relevant. The existence of a significant potential bias in the estimation of DGMM in this work thus led us to favor the system GMM (SGMM) estimator. Indeed, many results in the empirical literature (Blundell and Bond, 1998; Bun and Windmeijer, 2010) show that the SGMM estimator significantly improves gains in accuracy, and considerably reduces sampling bias, compared to the DGMM estimator when the regressors are weakly exogenous and correlated with the individual effect. Under these conditions, Blundell and Bond (2000) show that the SGMM estimator is more appropriate. This model simultaneously estimates the first difference equations and the level equations. In addition, the attractive property of the SGMM estimator is the possible assumption of the existence of endogenous regressors. Thus, despite the fact that recent simulation studies have shown that the properties of the SGMM estimator are better than those of the DGMM estimator, both DGMM and SGMM are used for empirical verification of the proposed model. We will use Sargan's test to analyze the validity of the chosen instruments. If the null hypothesis is not rejected, it means that there is no endogeneity problem in the model. The instruments used are thus validated. In addition, the first and second order tests of serial correlation (AR test (1) and AR test (2)) are effective on differentiated residuals (Arellano and Bond, 1991).

\subsection{Sample and Study Period}

The sample examined is composed of eighteen Tunisian banks (public and private, domestic and foreign) observed during the period from 2008 to 2018. The data are taken from the Central Bank of Tunisia (BCT), annual reports of banking activities, the Tunisian Professional Association of Banks and Financial Institutions (APTBEF), WDI (World Development Indicators) and WGI (World Governance Indicators).

\subsection{Empirical Analysis and Results}

We began our analysis by forming a basic model with three groups of variables: specific characteristics of banks, governance indicator and macroeconomic variables in Tunisia. Thus, in a first step, we test the basic model which is presented as follows:

$N P L_{i t}=\mu+\gamma N P L_{i, t-1}+$ BanksSpecific $c_{i t} \beta_{1}+$ GovernanceIndicator $_{i, t-1} \cdot \beta_{2}+$ Macroeconomic $_{i, t-1} \cdot \beta_{3}+\alpha_{\mathrm{i}}+\varepsilon_{i t}$,

$\mathrm{I}=1, \ldots \ldots \ldots . \mathrm{N}, \mathrm{t}=1, \ldots \ldots \ldots \mathrm{T}(2)$

With $N P L_{i t}$ is the value of the NPLs of bank $\mathrm{i}$ in year $\mathrm{t}$. $N P L_{i, t-1}$ is the value of NPLs of bank i in year $\mathrm{t}-1$. BankSpecific $_{i t}$ is the matrix of bank-specific indicators, GovernancelIndicator $_{i, t-1}$ is the matrix of governance indicators of bank $i$ at year $\mathrm{t}$, Macroeconomici,t-1 is the matrix of macroeconomic variables of bank i's country at year t-1. $\mathrm{a}_{i}$ is the bankspecific error for each bank, and $\varepsilon_{i t}$ is the remaining share of the error term. $\mathrm{N}$ is the number of banks, and $\mathrm{T}$ is the number of periods. $\gamma$ is the coefficient of the lagged dependent variable. $\beta_{1}, \beta_{2}$, and $\beta_{3}$ are the vectors of the parameters.
In equation (2), the macroeconomic and governance variables are lagged by one year. This approach follows similar research (Glogowski, 2008; Makri et al., 2014; Louzis et al., 2012). This is necessary when changes in the macroeconomic and governance environments lead to changes in NPLs (Skrabic Peric et al. 2018). The results of the basic model (2) are presented in Table (3).

Through this model, we will identify the factors that explain the volatility of NPLs of Tunisian banks. As already mentioned, we will use in this study individual (18 banks) and time (11 years) data from the two-dimensional panel data (i.e., $18 \times 11=198$ observations). The estimation of our model will be done according to two dynamic approaches: the method of generalized moments in difference (DGMM) and the method of generalized moments in system (SGMM).

Before outlining our econometric estimates, a descriptive analysis of our data that aggregates the observations of different individuals seems to be crucial. This first exploratory step ensures an understanding of the results that will be obtained from the regressions and proposes the characteristics and econometric methods that correspond to the phenomena revealed by the descriptive statistics. Table (2) presents, on the one hand, the disparity of the mean values of the explanatory variables and the variable to be explained and their standard deviations for the different banks in the sample, and on the other hand, the correlation matrix of the variables considered in our model.

Table (2) shows that the average NPL ratio for the sample for the study period 2008 to 2018 is approximately 14.804 . The minimum value of the variation in the ratio of ant NPLs recorded in Tunisia is of the order of zero (0), while the maximum is 77.34. It is therefore noticeable that the Tunisian banking sector is characterized by a high level of NPLs, given that unpaid credits relating to the household sectors have increased, especially over the period 2011-2016. Fig. (1) shows the evolution of the ratio of non-performing household loans in Tunisia. It can be seen that the curve shows a very volatile trend in the ratio for the period 2008 to 2018 .

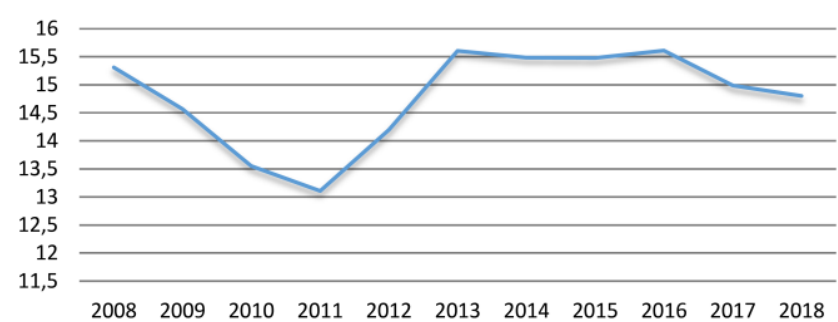

Fig. (1). NPL ratio of Tunisian banks (2008-2018).

In order to detect a possible relationship between the different variables, Table (2) presents the different correlation coefficients. This matrix takes into account the relationship observed between the different explanatory variables. Therefore, the correlation coefficient is an indicator that gives us an idea of the activity of the linear relationship between two variables. As this table shows, the correlation coefficients between the different explanatory variables are low. Thus, no variable will be excluded from the model. Between the first difference GMM method and the second difference GMM method, the first difference GMM estimator is chosen because it tends to be less biased when the sample size is small. 
Table (3) presents the results of the estimates of the GMM method in first difference and GMM in system of the dynamic model. Sargan's test for both GMM estimates shows that all the selected instruments are validated. The first and second order tests of the $\operatorname{AR}(1)$ and $\operatorname{AR}(2)$ serial correlation confirm the expected diagnoses. Thus, the AR(1) test rejects the null hypothesis of a first-order serial non-correlation. Diagnostic tests of all model specifications presented in table (3) show that model (2) is well specified. The results of the Sargan test indicate the validity of the selected instruments. In addition, the second order AR(2) autocorrelation test of differentiated residuals rejects the existence of autocorrelation. The AR(1) test indicates the existence of first-order autocorrelation of the differentiated residuals, an expected result.

The results in table (3) confirm that macroeconomic factors, bank-specific factors, and governance factors do explain the volatility of NPLs by Tunisian banks. These results also show that the lagged dependent variable of NPLs is statistically significant at the $1 \%$ threshold and positive, confirming the results of recent studies (Radivojević et al. 2019). There is then a positive and significant relationship between the NPL lagged variable and the current NPL rate. Since NPLs have a high degree of persistence, this expected result indicates that the NPL shock is likely to have a lasting effect on the banking system.

The estimates demonstrate the absence of a significant relationship between bank size and NPLs. The sign obtained is positive. This indicates that large Tunisian banks that manage their resources more efficiently are accepting risky projects. Indeed, these banks will be protected by the State in case of bankruptcy. This result is similar to those found by Louzis, Vouldis and Metaxas (2012) and $\mathrm{Hu}, \mathrm{Li}$ and Chiu (2004). However, it contradicts the one found by Skrabic Peric et al. (2018), who state that market-dominant banks use their market power to choose the best customers.

The bank's capital shows a negative and significant relationship at the 1\% threshold (DGMM) and at the 10\% threshold (SGMM) with the banks' NPLs. This shows that banks with large capital have fewer NPLs. It appears that Tunisian banks with a high level of capital act prudently when granting loans. Again, these banks avoid riskier customers because of the large potential losses to shareholders in the event of bank failure. This result confirms that found by Repullo (2004).

A negative and significant relationship was also found at the $1 \%$ threshold between ROA and the amount of classified debt, based on both dynamic panel estimation methods. This sign was predicted. It confirms the results found by several authors, such as Kolapo, Ayendi and Oke (2012), Louzis, Vouldis and Metaxas (2012) and Godlewski (2004). Indeed, a bank with high profitability has less incentive to generate revenues and is therefore less constrained to engage in risky activities such as granting risky loans. On the contrary, inefficient banks find themselves obliged to grant credit deemed risky and subsequently experience high levels of impaired loans.

According to the estimates of the two methods DGMM and SGMM, the "Financing" variable shows a positive and sig- nificant relationship at the 5\% threshold with NPLs of Tunisian banks. This sign is well expected. This result shows that Tunisian banks that are less dependent on deposits, and therefore more oriented towards external sources of financing, accept riskier projects. And consequently, the transfer of risk from the internal capital market would be more visible. This result is similar to those found by Makri, Tsagkanos and Bellas (2014) and by Anginer et al. (2017).

In our study, we also considered foreign ownership of the bank as an important variable in modeling risk in emerging countries. According to GMM first difference estimates, the Dummy (OWNER) variable is negatively and significantly correlated to the $10 \%$ threshold with bank NPLs. It appears that foreign banks take less risk than domestic banks. This result contradicts those found by Anginer, Cerutti and Martinez Peria (2017) and Ashraf and Arshad (2017), but confirms the result found by Skrabic Peric et al. (2018). Thus, a high ratio of foreign banks in the banking system is the consequence of a decline in NPLs in the entire system. However, this does not suggest that foreign banks are less risky than domestic banks; this means that banking systems containing a majority of foreign banks become more risk-averse.

All lagged macroeconomic variables are statistically significant and show the expected signs. The lagged variable "Real interest rate" shows a positive and significant relationship at the 5\% threshold with the NPLs of Tunisian banks, according to the results of the GMM method in first difference (no significance recorded according to the SGMM method in first difference). This positive sign is predictable through an increase in debt service costs. This finding is justified by the fact that if borrowers benefit from loans at variable rates, they can no longer honor their commitments when the interest rate increases. In other words, a sudden increase in interest rates could weaken the financial situation of borrowers whose loans are contracted at variable rates. This result confirms those found by Tanaskovic and Jandric (2015) and Skrabic Peric et al. (2018).

Fairly consistent with theory, the results of the firstdifference GMM estimates confirm a negative and significant relationship at the 5\% threshold between the GDP growth rate and NPLs (no significance recorded using the first-difference SGMM method). This expected result is similar to those found by Caprio and Kingebiel (2003), Fofack (2005), Jimenez and Saurina (2006), and Khemraj and Pasha (2009). That said, the improvement in the real economy is likely to see a reduction in the NPL portfolios of Tunisian banks.

Concerning the unemployment rate, a positive and significant relationship was found at a level of $10 \%$ with the NPL ratio, according to both the DGMM and SGMM methods. This sign was well expected. It confirms the results found by Louzis et al (2012) and Khemraj and Pasha (2009). In fact, unemployed clients are unable to meet their commitments and repay the loans, thus increasing the level of NPLs of banks. Similarly, inflation has led to an erosion of the real repayment value. In this case, the dynamics of the two variables (GDP growth rate and the unemployment rate) are closely linked to households and firms and their ability to meet their financial obligations. An increase in GDP generally reflects greater income flows to households and an in- 
crease in the profitability of firms. An increase in the unemployment rate limits the current and future purchasing power of households and is generally related to a decrease in the production of goods and services. Unemployment negatively affects household cash flows and increases the debt burden.

The delayed "Exchange Rate" variable positively and significantly affects the $1 \%$ threshold (DGMM) and the 5\% rate (SGMM) of NPLs of Tunisian banks. This expected result confirms the one found by Jakubík and Reininger (2013) for European banks and by Dash and Kabra (2010) for Indian banks. It shows that a depreciation of the Tunisian dinar against the US dollar may worsen the country's trade balance, as the prices of imported goods and services will naturally soar in local currency, which could lead to a decline in the purchasing power of the Tunisian consumer.

Table 2. Descriptive Statistics and Correlation Matrix for Tunisian Banks.

\begin{tabular}{|c|c|c|c|c|c|c|c|c|c|c|c|c|}
\hline Variable & NPL & INF & TXIN & GDP & TXG & ТХСНО & CORR & SIZE & FIN & CAPITAL & ROA & OWNER \\
\hline Obs & 186 & 198 & 198 & 198 & 198 & 198 & 198 & 188 & 188 & 188 & 188 & 188 \\
\hline Mean & 14.804 & 4.529 & 4.640 & 2.316 & 1.771 & 15.209 & -0.124 & 15.058 & 1006.899 & 12.550 & 0.620 & 0.765 \\
\hline Std. Dev. & 13.165 & 1.116 & 0.809 & 1.649 & 0.443 & 1.719 & 0.089 & 1.538 & 3451.163 & 13.149 & 1.789 & 0.424 \\
\hline Min & 0 & 3.240 & 3.5 & -1.917 & 1.232 & 12.443 & -0.303 & 11.01 & 10.11 & -1.62 & -10.05 & 0 \\
\hline Max & 77.34 & 7.307 & 6.75 & 4.237 & 2.646 & 18.334 & -0.036 & 19.82 & 28127.86 & 88.3 & 3.4 & 1 \\
\hline NPL & 1.0000 & & & & & & & & & & & \\
\hline INF & 0.0224 & 1.0000 & & & & & & & & & & \\
\hline TXIN & 0.0146 & $0.7678^{*}$ & 1.0000 & & & & & & & & & \\
\hline GDP & 0.0194 & $0.2395 *$ & $0.3461 *$ & 1.0000 & & & & & & & & \\
\hline TXG & 0.0220 & $0.6974 *$ & $0.5867^{*}$ & $-0.1843^{*}$ & 1.0000 & & & & & & & \\
\hline TXCHO & -0.0178 & 0.0961 & $-0.4191 *$ & $-0.5965^{*}$ & $0.2087 *$ & 1.000 & & & & & & \\
\hline CORR & 0.0067 & $0.4220 *$ & -0.0800 & $-0.4398^{*}$ & $0.4811^{*}$ & $0.8224^{*}$ & 1.000 & & & & & \\
\hline SIZE & $0.3144 *$ & $0.1520 *$ & 0.0801 & -0.0756 & $0.2323^{*}$ & 0.0929 & $0.1613^{*}$ & 1.000 & & & & \\
\hline FIN & 0.0989 & -0.1118 & -0.0207 & 0.0312 & -0.1314 & -0.1299 & $-0.1709 *$ & $0.1445^{*}$ & 1.000 & & & \\
\hline CAPITAL & -0.0347 & -0.1153 & -0.0496 & 0.0241 & -0.1183 & -0.0978 & $-0.1574 *$ & $0.3669 *$ & $0.5425^{*}$ & 1.000 & & \\
\hline ROA & $-0.5491 *$ & 0.0064 & 0.1051 & 0.0775 & -0.0014 & $-0.1751^{*}$ & $-0.1588 *$ & $-0.4493 *$ & $-0.2081 *$ & $-0.2363^{*}$ & 1.000 & \\
\hline OWNER & $-0.4390 *$ & 0.0125 & 0.0047 & -0.0114 & 0.0224 & 0.0132 & 0.0182 & $-0.5249^{*}$ & -0.1402 & $-0.1443^{*}$ & $0.3981^{*}$ & 1.000 \\
\hline
\end{tabular}

Note: * indicate statistical significance at $5 \%$.

Source: Authors' calculations.

Table 3. The Results of the GMM Estimates of a Dynamic Panel Data Model.

\begin{tabular}{|c|c|c|}
\hline & GMM in First Difference & First-Order SGMM \\
\hline NPL (-1) & NPL & $0.463^{* * *}$ \\
\hline & $0.352^{* * *}$ & $(0.003)$ \\
\hline ROA & $(0.019)$ & $-2.550^{* * *}$ \\
\hline & $-3.222^{* * *}$ & $(-4.07)$ \\
\hline SIZE & $(-9.49)$ & 0.386 \\
\hline CAPITAL & 0.498 & $(0.36)$ \\
\hline & $(0.85)$ & $-0.278 *$ \\
\hline
\end{tabular}




\begin{tabular}{|c|c|c|}
\hline FIN & $0.00156^{* *}$ & $0.00107 * *$ \\
\hline \multirow[t]{2}{*}{$\operatorname{TXIN}(-1)$} & $1.097^{* *}$ & 0.265 \\
\hline & $(2.41)$ & $(0.54)$ \\
\hline TXG (-1) & $5.065^{* * *}$ & $4.982 * *$ \\
\hline \multirow[t]{2}{*}{ TXCHO (-1) } & $0.619 *$ & $0.621^{*}$ \\
\hline & $(1.81)$ & $(2.01)$ \\
\hline \multirow[t]{2}{*}{ INF (-1) } & $-2.806 * * *$ & $-1.931 * * *$ \\
\hline & $(-6.84)$ & $(-4.25)$ \\
\hline \multirow[t]{2}{*}{ CORR (-1) } & $17.17^{* *}$ & $20.07^{* *}$ \\
\hline & $(2.68)$ & $(2.62)$ \\
\hline \multirow[t]{2}{*}{ OWNER } & $-5.669 *$ & -12.47 \\
\hline & $(-1.84)$ & $(-0.94)$ \\
\hline \multirow[t]{2}{*}{ _CONS } & 24.55 & 32.12 \\
\hline & $(2.09)$ & $(1.46)$ \\
\hline Number of observations & 186 & 186 \\
\hline
\end{tabular}

(.) $t$ of Student

$* * *$ Significance at $1 \%, * * 5 \%, * 10 \%$

$\mathrm{AR}(1)$ et $\mathrm{AR}(2)$ are tests of serial correlation of first and second order of Arellano et Bond.

Source: Authors' calculations.

As for the lagged variable "Inflation", both dynamic panel estimation methods show the same results: a significant negative correlation at the $1 \%$ threshold with problem loans. Inflation can reduce the real income of borrowers when wages are rigid and also allows for the erosion of the real value of repayment. This result is similar to those obtained by Khemraj and Pasha (2009) and Dash and Kabra (2010) and Nkusu (2011).

As an indicator of governance, we used the variable "Corruption". The results of the estimates of the two methods DGMM and SGMM show a positive and significant correlation at the 5\% threshold between the lagged variable "Corruption" and the NPLs of Tunisian banks. The sign is well expected. This result contradicts those found by La Porta (1997, 1998) and by Beck, Demirguç-kunt and Levine (2005), but confirms the result found by Weill (2009). Thus, corruption could, against all expectations, improve bank lending. Indeed, since adverse selection leads to a restriction of the credit granted, corruption, by facilitating the greasing of the mechanism, increases the quantity of loans granted and thus improves the flexibility of the bank lending process, which will generate greater credit risk and therefore more NPLs.

\section{IS THE REVOLUTION ONE OF THE FACTORS EXPLAINING THE VOLATILITY OF TUNISIAN BANKS' NPLS?}

The banking sector was particularly affected by the context of the post-revolution crisis as the ability of Tunisian banks to overcome financial instability has become a major concern. Indeed, they have become extremely vulnerable to any negative shock: economic slowdown, lack of liquidity, drop in investments, increase in bad debts, weak recovery... Thus, the "2011 revolution" is likely to have a significant impact on banks' NPLs. Indeed, due to the national gloomy economic climate and the fallout from the revolution of January 14, 2011 , the banking sector is encountering considerable difficulties, particularly in terms of the deteriorating quality of loans and profitability. Thus, and in a second step, we improve our model (2) by introducing a dummy variable "Rev- 
olution" in order to analyze whether or not this crisis is one of the factors that explain the volatility of Tunisian banks' NPLs.

In Tunisia, the monetary policy adopted after the revolution shows that 2011 is characterized by a liquidity problem and a poor functioning of the payments system. The measures taken were to reduce the reserve requirement rates three times during 2011 in order to ease inflationary pressures, which freed up liquidity (over one billion dinars) for the benefit of the banking system. These measures have most likely succeeded in preventing a "credit crunch", by encouraging credit to the economy.

Thus, in our second model, we add a new variable specific to banks, namely, liquidity risk. The work of Skrabic Peric et al. (2018) which focused on loans granted to foreign banks in CEE countries (Central and Eastern European countries) highlighted the strong correlation between bank liquidity and bad debts. More precisely, the results showed a positive relationship between these two variables. We expect a positive correlation between liquidity risk and NPLs because, in situations where banks have high liquidity, the manager is motivated to increase lending in order to achieve the expected rate of return. In such a situation, bank loans may decrease and therefore create additional risk for the bank.

Our database covers the period before and after the Tunisian revolution (2008-2018). We seek to examine the impact of this crisis on NPLs. This explains the introduction of the variable "Revolution" in model (3) which is as follows:

$N P L_{i t}=\mu+\gamma N P L_{i, t-1}+$ BanksSpecific ${ }_{i t} . \beta_{1}+$ GovernanceIndicator $_{i, t-1 .} \beta_{2}+$ Macroeconomic $_{i, t-1 .} . \beta_{3}+$ Revolution $_{\mathrm{i}, t} . \beta_{4}+\alpha \mathrm{i}+$ $\varepsilon_{i t},(3)$

With Revolution ${ }_{i, t}$ is a dummy variable, and $\beta_{4}$ is the coefficient of this variable. We also introduce liquidity risk as a new variable specific to banks into this model. To estimate the model (3), we will use the SGMM method. The results are shown in Table (4). Estimates show that the liquidity risk has a positive and significant correlation at $10 \%$ threshold with the NPLs of Tunisian banks. This sign is expected. It corroborates the results found by Skrabic Peric et al. (2018). Tunisian banks which have high liquidity and which should justify the cost of their resources can be encouraged to accept riskier projects (Anginer et al., 2017).

The variable "Revolution" presents a positive though not significant relationship with the NPLs of Tunisian banks based on the estimation results of SGMM model. In order to examine the robustness of these results, and particularly to assess the effect of the revolution on the volatility of the NPLs of Tunisian banks, we decomposed the sample into two sub-samples: pre-revolution period and post-revolution period. The results, shown in Table (4) suggest that the ROA and the ownership structure negatively and significantly affect the NPLs of the banks in the two periods, while the capital affects them positively. In the post-revolution period, the contributions of the unemployment rate and the GDP are significant (negative and significant coefficients respectively at the $10 \%$ and $5 \%$ thresholds), while that of other macroeconomic factors is not significant. In the same period, the size and the liquidity risk explain the volatility of NPLs with negative and significant coefficients at the $10 \%$ thresholds.
During the pre-revolution period, the results show that the exchange rate positively and significantly affects the NPL level at the $10 \%$ threshold. It appears that bank-specific factors explain well the volatility of NPLs, especially in the post-revolution period.

\section{NPL TRENDS, THEIR MACROECONOMIC AND GOVERNANCE EFFECTS AND THE REVOLUTION EFFECT}

This section explores the feedback effects of the banking sector on the real economy. In particular, we will focus on the relationship between the NPLs of Tunisian banks, other macroeconomic and governance factors and the revolution factor. Assessing these relationships in terms of causality, magnitude and duration could shed light on the macrofinancial vulnerabilities that are associated with the recent NPL volatility in Tunisia.

We present, in what follows, the empirical estimation methodology that we have chosen for this analysis, namely, VAR panel model (PVAR), then we discuss the results obtained.

\subsection{Empirical Estimation Methodology}

The PVAR methodology is a useful tool for assessing the magnitude and duration of effects. This technique combines the traditional VAR approach, which considers all variables in the system as endogenous, with the panel data approach which considers unobserved individual heterogeneity. The advantage of this methodology is that it does not require any assumptions about the direction of the feedback between the variables in the model. The PVAR model of Binder, Hsiao and Pesaran (2005) and its expansion introduced by Sigmund and Ferstl (2019) is as per the following:

$y_{i, t}=\mu+\sum_{l=1}^{p} A_{l} Y_{i, t-1}+\varepsilon_{i, i}$

where $y_{i t} \epsilon R^{m}$ is a vector $(\mathrm{m} \times 1)$ of endogenous factors for the I-th cross-sectional unit $(\mathrm{I}=1.2, \ldots, \mathrm{N})$ at time $(\mathrm{t}=1.2$, ..., T), $\varepsilon_{i t} \in R^{m}$ is a vector $(\mathrm{m} \times 1)$ of irritations, $\mu_{i}$ is a vector $(\mathrm{m} \times 1)$ of explicit individual impacts, and $\mathrm{p}$ is the carryover length of the PVAR model. Stationarity requires that all the units underlying the model's foundations lie within the unit circle. Boundary homogeneity is expected for the $(\mathrm{m} \times \mathrm{m})$ frame of $A_{l}$. A PVAR model is thus a mixture of a dynamic soliton condition map model (DPM) and a vector autoregressive model (VAR).

Applying the principal contrast change to condition (4), we get:

$\Delta y_{i, t}=\sum_{l=1}^{P} A_{l} \Delta y_{i, t-l}+\Delta \varepsilon_{i, t}$

Where $\Delta$ alludes to the administrator of the primary contrast.

As per Binder et al (2005), the second conditions for slacked endogenous factors and foreordained factors are:

$E\left[\Delta \varepsilon_{i, t} y_{i, j}^{T}\right]=0$

with $\mathrm{j} \in\{1, \ldots, \mathrm{T}-2\}$ and $\mathrm{t} \in$ ?? $\Delta$. Stacking on $\mathrm{t}, \mathrm{Eq}(5)$ is composed as :

$\Delta Y_{i}=\sum_{l=1}^{p} \Delta Y_{i, l} A_{l}^{T}+\Delta E_{i}$ 
Where $\Delta Y_{i}, \Delta Y_{i}, 1$ et $\Delta E_{i}$ are frameworks $((\mathrm{T}-1-\mathrm{p}) \times \mathrm{m})$. Along these lines, the states of stacked minutes for every I are as per the following ${ }^{1}$ :

$\mathrm{E}\left[\mathrm{Q}_{\mathrm{i}}^{\mathrm{T}}\left(\Delta \Delta_{\mathrm{i}}\right)\right]=0(8)$

Where $Q_{i}$ is the stacked type of $q_{i, t}$, with $q_{i, t} T=\left(y_{i, t-p-1^{T}}, y_{i, t-p-2^{T}, \ldots, y_{i, 1} T}\right)$ for $\mathrm{t} \in\{\mathrm{p}+2$, $\ldots, \mathrm{T}\}$ and

$Q_{i}=\left(\begin{array}{ccc}q_{i, p+2}^{T} & 0 \ldots & 0 \\ 0 & q_{i, p+3}^{T} & 0 \\ 0 & 0 \ldots & q_{i, T}^{T}\end{array}\right)$

According to the second condition (7), the minimization issue is :

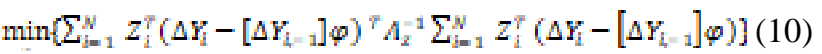

Where $\varphi$ gives model appraisals (5) utilizing the summed up technique for minutes (GMM) and $A_{z}$ is the weighting grid dependent on the one-venture assessment method of Binder et al. $(2005)^{2}$. The decision of the ideal weighting lattice decreases the asymptotic inclination in the assessment. Fixed impacts are wiped out by actualizing first contrasts.

In our PVAR model, there are 8 endogenous variables so that the vector $Y_{i t}$ is given by:

$Y_{i t}=\left[\mathrm{NPL}_{i, t}, \Delta \mathrm{GDP}_{i, t}, \Delta \mathrm{INF}_{i, t}, \mathrm{TXCHO}_{i, t}, \mathrm{TXIN}_{i, t}, \mathrm{TXG}_{i, t}\right.$, $\mathrm{CORR}_{i, t}$, Revolution $\left._{i, t}\right]$

$\mathrm{NPL}_{i, t}$ is the litigation rate calculated by the ratio of bad debts to the total loans of bank $\mathrm{i}$ in year $\mathrm{t}, \mathrm{GDP}_{i, t}$ is the annual percentage growth, $\operatorname{TXIN}_{i, t}$ is the average real lending rate, $\mathrm{TXG}_{i, t} \mathrm{t}$ is the exchange rate, $\mathrm{TXCHO}_{i, t}$ is the unemployment rate, $\mathrm{INF}_{i, t}$ is the inflation rate, $\mathrm{CORR}_{i, t}$ is corruption, and finally the variable Revolution ${ }_{i, t}$ which is a dummy variable.

Table 4. Results of SGMM Estimates (Revolution Effect).

\begin{tabular}{|c|c|c|c|}
\hline & $\begin{array}{c}\text { First-order } \\
\text { SGMM }\end{array}$ & $\begin{array}{c}\text { Pre- } \\
\text { revolution } \\
\text { Period }\end{array}$ & $\begin{array}{c}\text { Post- } \\
\text { revolution } \\
\text { Period }\end{array}$ \\
\hline & NPL & NPL & NPL \\
\hline NPL (-1) & -0.333 & $0.754 * * *$ & $0.818^{* * *}$ \\
\hline RL & $(-0.91)$ & $(27.90)$ & $(7.26)$ \\
\hline & $0.088^{*}$ & $0.020^{*}$ & $-0.045^{*}$ \\
\hline ROA & $(3.02)$ & $(2.34)$ & $(-2.30)$ \\
\hline & $-3.171^{* * *}$ & $-0.803 *$ & $-1.098^{* *}$ \\
\hline & $(-4.42)$ & $(-3.04)$ & $(-2.39)$ \\
\hline
\end{tabular}

\footnotetext{
${ }^{1}$ The main contrast change exists for $t \in\{p+2, \ldots, T\}$. We assign the arrangement of lists $t$, for which the change exists by ?? $\Delta$. The utilization of the foreseen symmetrical change of Arellano and Bover (1995) delivered subjectively comparable outcomes to those introduced underneath.

${ }^{2}$ See likewise the nitty gritty specialized conversation in Sigmund and Ferstl (2019).
}

\begin{tabular}{|c|c|c|c|}
\hline SIZE & 1.124 & -0.218 & $-2.089^{*}$ \\
\hline & $(1.18)$ & $(-0.55)$ & $(-3.03)$ \\
\hline \multirow[t]{2}{*}{ CAPITAL } & $-0.347 *$ & $0.064 *$ & $0.182 * *$ \\
\hline & $(-2.12)$ & $(1.76)$ & $(2.75)$ \\
\hline \multirow[t]{2}{*}{ FIN } & $0.0002 *$ & 0.0001 & $0.001 * * *$ \\
\hline & $(2.03)$ & $(1.13)$ & $(4.07)$ \\
\hline \multirow[t]{2}{*}{ TXIN (-1) } & -0.554 & -0.831 & 0.404 \\
\hline & $(-1.15)$ & $(-1.28)$ & $(0.92)$ \\
\hline \multirow[t]{2}{*}{ TXG (-1) } & 7.232 & $16.778^{*}$ & -0.755 \\
\hline & $(1.53)$ & $(2.23)$ & $(-0.47)$ \\
\hline \multirow[t]{2}{*}{ TXCHO (-1) } & -0.527 & -0.177 & $-2.027 *$ \\
\hline & $(-0.50)$ & $(-0.37)$ & $(-2.12)$ \\
\hline \multirow[t]{2}{*}{ INF (-1) } & -2.049 & -1.033 & 0.603 \\
\hline & $(-1.71)$ & $(-1.54)$ & $(1.36)$ \\
\hline \multirow[t]{2}{*}{ GDP (-1) } & 0.396 & 0.039 & $-1.554 * *$ \\
\hline & $(1.21)$ & $(0.35)$ & $(-2.38)$ \\
\hline \multirow[t]{2}{*}{$\operatorname{CORR}(-1)$} & 17.170 & 16.115 & 4.176 \\
\hline & $(1.33)$ & $(1.35)$ & $(0.14)$ \\
\hline \multirow[t]{2}{*}{ OWNER } & $-11.795^{*}$ & $-2.845^{* * * *}$ & $-18.095 * *$ \\
\hline & $(-2.14)$ & $(-3.17)$ & $(-2.41)$ \\
\hline \multirow[t]{2}{*}{ REVOLUTION } & 1.921 & & \\
\hline & $(0.26)$ & & \\
\hline \multirow[t]{2}{*}{ _CONS } & 23.868 & -8.869 & $77.624 * * *$ \\
\hline & $(1.47)$ & $(-0.61)$ & $(3.39)$ \\
\hline Number of observations & 168 & 80 & 88 \\
\hline AR(1) Test. p-value & 0.043 & 0.102 & 0.097 \\
\hline $\operatorname{AR}(2)$ Test. p-value & 0.284 & 0.156 & 0.919 \\
\hline Number of instruments & 19 & 15 & 18 \\
\hline Sargan test (p-value) & 0.458 & 0.098 & 0.086 \\
\hline
\end{tabular}

(.) $\mathrm{t}$ of Student

*** Significance at $1 \%, * * 5 \%, * 10 \%$

$\mathrm{AR}(1)$ et $\mathrm{AR}(2)$ are tests of serial correlation of first and second order of Arellano et Bond.

Source : Authors' calculations.

Before estimating the VAR panel, a number of precautions relating to panel data and VAR models are taken. First, the stationarity of the variables is examined by the IPS test. This test is preferred over the others because Hurlin and Mignon (2007) show that it is convergent when $\mathrm{T}$ is low (T less than 30). Table (5) shows that the variables GDP, TXCHO and Revolution are stationary at level, on the other hand, the variables NPL, INF, TXIN, TXG and Corruption are integrated of order 1 . To avoid a fallacious regression, it is necessary to 
perform the cointegration test in order to highlight the presence or absence of a long-term relationship between the variables. Thus, the Kao test was performed because it provides a better result for panels of reduced time dimension according to Hurlin and Mignon (2007) ${ }^{3}$. The results suggest an absence of cointegration in the model at the $5 \%$ threshold.

In addition, as with standard VARs, estimating the VAR panel requires determining the optimal lag before specifying the model. To do this, several criteria are used in the literature. In some studies such as those by Boutbtane et al. (2010) and Carstensen et al. (2009), the optimal lag is determined based on the LM test (Lagrange multiplier). Others, in contrast, use the Akaike and Schwarz criteria to determine the optimal lag as in standard VARs (Miller et al., 2011). Based on the literature, the Akaike and Schwarz criteria are used to determine the optimal lag. Table (6) shows the two information criteria used for different lags of the VAR model.

Table 5. The Results of IPS Tests.

\begin{tabular}{|c|c|c|}
\hline Variables & $\begin{array}{c}\text { IPS Level Test } \\
\text { Calculated Value }\end{array}$ & $\begin{array}{c}\text { IPS test in first difference } \\
\text { Calculated Value }\end{array}$ \\
\hline NPL & -0.82099 & -1.23167 \\
\hline$\Delta \mathrm{GDP}$ & $0.3453 * * *$ & $0.1244 * * *$ \\
\hline$\Delta \mathrm{INF}$ & 0.80423 & -0.87506 \\
\hline TXCHO & $-3.04687^{* * *}$ & $-1.44789^{*}$ \\
\hline TXIN & 2.39295 & -0.17291 \\
\hline TXG & 13.9680 & 2.89644 \\
\hline CORR & -1.08166 & -0.51168 \\
\hline Revolution & $1.2688^{*}$ & $0.6416^{*}$ \\
\hline
\end{tabular}

*stationary at threshold $1 \%, * * *$ stationary at threshold $10 \%$.

Table 6. The Information Criteria of Akaike and Schwarz.

\begin{tabular}{|c|c|c|c|c|}
\hline Criteria & VAR(1) & $\operatorname{VAR}(2)$ & $\operatorname{VAR}(3)$ & VAR(4) \\
\hline Akaike & 34.909 & $34.600^{*}$ & 34.608 & 34.635 \\
\hline Schwartz & $35.917^{*}$ & 36.472 & 37.344 & 38.236 \\
\hline
\end{tabular}

We note that the two criteria do not lead to the same results. We will limit ourselves to the Akaike criterion and therefore choose the number of lags equal to 2 , since these information criteria reach their minimum when the lag is equal to 2 .

The dynamic behavior of this model is evaluated using impulse response functions that describe the reaction of one variable in the system to an innovation of another variable, while keeping all other shocks constant. Confidence intervals are generated by Monte Carlo simulations. Generally, orthogonal shocks in the VAR model are identified by the

\footnotetext{
${ }^{3}$ Test proposed by Im, Pesaran and Shin (IPS) in a series of contributions (1997, 2002 and 2003). These authors were the first to develop a test allowing under alternative hypothesis not only a heterogeneity of the autoregressive root, but also a heterogeneity as for the presence of a unit root in the panel.
}

Cholesky decomposition which implies that the variables appearing first in the equation are considered more exogenous than those appearing later in the model, suggesting that they affect subsequent variables simultaneously and with a delay; whereas the variables at the end of the equation affect the first variables only with a delay. However, in our study, to examine the response of one (endogenous) variable to an impulse in another (endogenous) variable, we rely on the Generalized Impulse Response Functions (GIRF) of Pesaran and Shin (1998). Unlike Orthogonalized Impulse Response Functions (OIRF), where the shocks underlying the model are orthogonalized using the Cholesky decomposition before calculating the impulse responses, the GIRFs are not affected by the order of the variables in the PVAR model and take full account of the historical correlation models observed between the different shocks. The justification of GIRFs compared to OIRFs is twofold. First, the theoretical framework for this component of the empirical literature is limited at best 4 , and second, the large number of variables we use make proper sequencing almost impossible5.

\subsection{Discussion of Estimation Results}

The PVAR approach will allow us to examine both the NPLs of Tunisian banks and a number of factors. In particular, we consider a PVAR model which contains a governance variable (corruption) and macroeconomic variables (GDP, real interest rate, inflation rate, unemployment rate and exchange rate), without forgetting the "Revolution" variable which is a dummy variable in our model. In the following, the impulse responses are examined and the variance decomposition.

It should be remembered that the objective through the specification of the PVAR model is to carry out impulse analyzes to better understand the reaction of NPLs following shocks on inflation, the real interest rate, GDP, the exchange rate, unemployment, corruption and revolution. The impulse response functions are taken directly from the dynamic multipliers. They inform us, on the one hand, about the directional evolutions of the variables, and, on the other hand, about the magnitude of these deviations. The analysis of the impulse response functions makes it possible to measure the impact of a shock on the model variables and to outline the effect of an innovation shock on the current and future values of the variables (Fig. 2).

\section{NPL RESPONSE TO SHOCKS OF OTHER VARIA- BLES}

The results analysis of the impulse response functions shows that the shocks undergone by the variables are not transient, because the variables do not find their long-term equilibrium after the 10 periods and even seem to find a new equilibrium path. We can note that an increase in the exchange rate first decreases the level of NPLs of Tunisian banks, which reaches its maximum drop during the second year. A positive

\footnotetext{
${ }^{4}$ See Holden, Natvik and Vigier (2018) for an equilibrium theory that takes into account the possibility that ratings affect the performance of assessed objects.

${ }^{5}$ Granger causality tests in our PVAR model (available on request) do not provide clear guidance on the order of variables as they indicate bidirectional causality.
} 
shock to the exchange rate immediately and negatively affects NPLs. A positive shock on the inflation rate and the

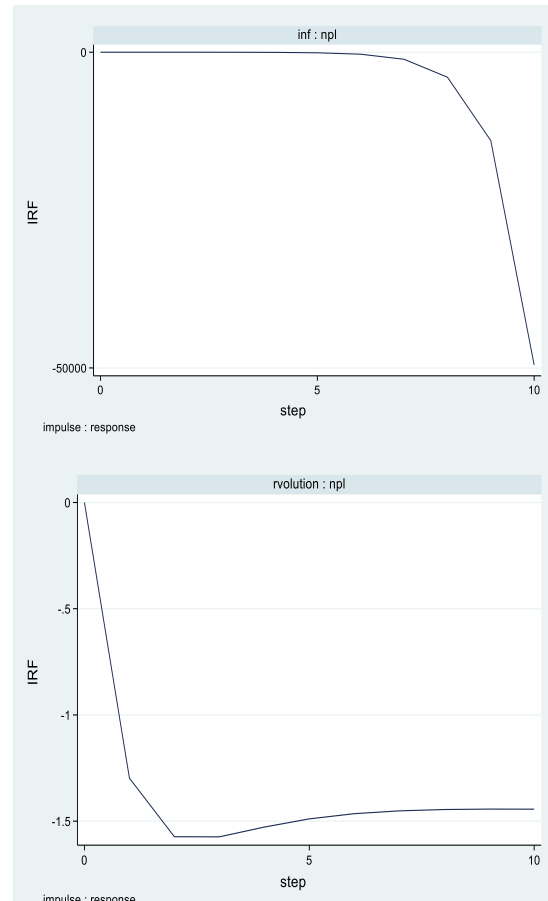

$$
\text { impuise: : response }
$$

$\operatorname{trin}: \operatorname{mp}$

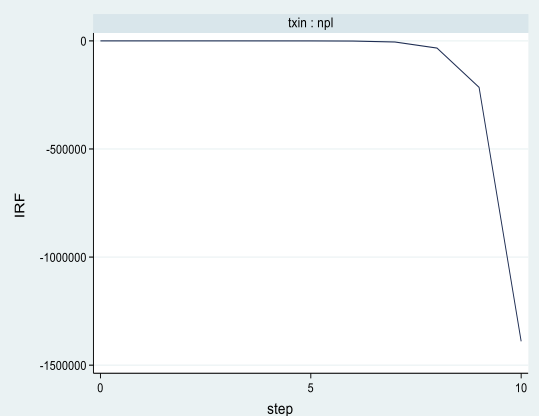

impulse : response

$\operatorname{txg}: n p \mid$

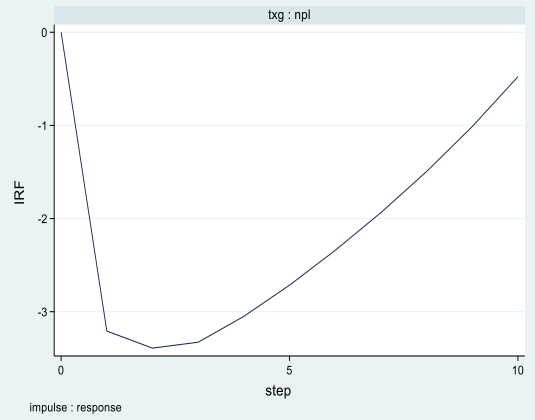

real interest rate produces negative effects that are not immediate on the level of NPL which decreases and reaches its
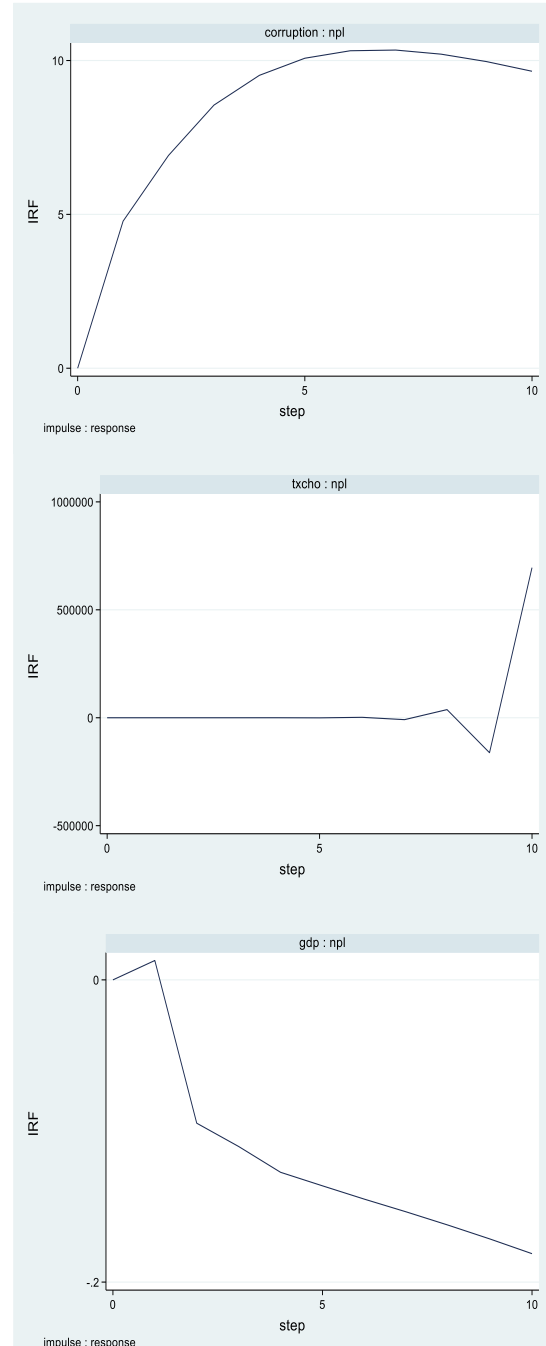

Fig. (2). The impulse response functions.

Table 5. Decomposition of the Variance of Forecast Errors.

\begin{tabular}{|c|c|c|c|c|c|c|c|c|c|}
\hline \multirow{4}{*}{ NPL } & Horizon & NPL & INF & GDP & TXCHO & TXIN & TXG & CORR & Revolution \\
\cline { 2 - 10 } & 1 & 100 & 0 & 0 & 0 & 0 & 0 & 0 \\
\cline { 2 - 10 } & 2 & 99.9987 & 1.71562 & 0.00123 & 37.59406 & 0.22614 & 0.21983 & 0.3534 & 0.34818 \\
\cline { 2 - 10 } & 3 & 99.9641 & 49.5188 & 0.03583 & 21.83351 & 6.00332 & 0.28238 & 0.64793 & 0.48784 \\
\hline
\end{tabular}




\begin{tabular}{|c|c|c|c|c|c|c|c|c|c|}
\hline \multirow{6}{*}{4} & 99.9465 & 94.44135 & 0.05346 & 24.69806 & 72.35924 & 0.3101 & 0.94591 & 0.5347 \\
\cline { 2 - 9 } & 5 & 99.9331 & 98.64863 & 0.06687 & 24.06241 & 94.9268 & 0.31846 & 1.2223 & 0.54793 \\
\cline { 2 - 9 } & 6 & 99.9245 & 98.23724 & 0.07544 & 24.18981 & 93.53405 & 0.31681 & 1.47323 & 0.54927 \\
\cline { 2 - 9 } & 7 & 99.9185 & 97.97149 & 0.08142 & 24.16361 & 93.15941 & 0.30915 & 1.69638 & 0.54665 \\
\cline { 2 - 9 } & 9 & 99.9143 & 97.88294 & 0.0857 & 24.16894 & 93.09921 & 0.29769 & 1.89237 & 0.543 \\
\cline { 2 - 9 } & 99.9111 & 97.85691 & 0.08889 & 24.16785 & 93.09015 & 0.28392 & 2.0631 & 0.53936 \\
\hline
\end{tabular}

minimum level in 9 periods, then it stabilizes on a new equilibrium path. The reaction of the NPL level to a shock to GDP growth is not immediate. From the first year, the growth rate decreases sharply and reaches its minimum level in the second period. As for the effect of the positive shock of corruption on the level of NPLs, we can see from the graphs below that it is positive and immediate. The NPL level rises sharply over the first three periods and then stabilizes at a positive equilibrium path. The reaction of the NPL level to a shock to the unemployment rate is not immediate and does not show a significant impact. As for the effect of the positive shock of the revolution on the NPL level, we note that it is significant and negative; this effect records a recovery from the third year to stabilize at a negative equilibrium path.

\section{THE DECOMPOSITION OF THE VARIANCE OF FORECAST ERRORS}

The decomposition of the variance makes it possible to understand the direction and the magnitude of the evolution of a system through the expected forecast deviations, that is to say the extent to which the variables interact with each other (Bourbonnais, 2003). In addition, the variance decomposition allows an analysis on the contribution of each innovation to the total variance of the forecast error. In other words, it gives an idea of the importance of each variable in the model (Table 5).

The results presented in Table (5) indicate that the variance of the forecast error of NPL is $99 \%$ due to its own innovations, $97 \%$ to inflation and $93 \%$ to real interest rate. Corruption explains only $2.21 \%$ of the variance of NPL forecast error, while the revolution explains only $0.53 \%$ of the latter.

\section{COVID-19: WHAT ARE THE IMPLICATIONS FOR THE TUNISIAN BANKING SECTOR AND THE NPL MARKET?}

The new coronavirus crisis (COVID-19) broke out in China and soon became a health crisis. The stock markets experienced several shockwaves from February 2020, as financial volatility continued to rise amid COVID-19 uncertainty (Albulescu, 2020). Due to the COVID-19, the economy suddenly came to a halt. This is likely to result in high levels of NPLs. High levels of these loans are problematic as they deteriorate bank balance sheets, slow credit growth and delay economic recovery (Aiyar et al., 2015; Kalemli-Ozcan et al., 2015). The persistence of high NPL ratios was a concern in several countries after the 2008-2012 crisis, and the COVID19 pandemic may cause the NPL problem to re-emerge. So how can Tunisian banks navigate the post-COVID-19 NPL landscape?

Although the economic impacts are very difficult to measure at this stage of the COVID-19 health crisis, Tunisian banks will now face a big problem that is just as serious as the decline in net banking income and customer deposits: the significant weight of unpaid debts which will undermine their cash flow. In other words, the concern lies in the fact that the current health crisis, the duration of which is difficult to predict, will affect the repayment capacity of customers, with the consequence of worsening the quality of loan portfolios as well as that of the profitability of Tunisian banks (Ben Gamra, 2020).

Prior to the COVID-19 health crisis, bad debts already accounted for $20-24 \%$ of GDP, making the Tunisian banking system among the most targeted by NPL in the world. After this severe health crisis, the financial profiles of banks will deteriorate considerably. Indeed, Tunisian banks were already grappling with a significant asset weight problem. At the end of 2019, NPLs represented on average $14 \%$ of total loans and provision coverage only 55\% (Global Ratings and Central Bank of Tunisia, 2020). Thus, the increase in the levels of provisions to be reported as provided for by the circular of the Central Bank of Tunisia (BCT) and the decrease in net banking income will generate losses for the banks. These losses will reduce their equity and therefore their solvency, which will affect their ability to raise capital in order to continue to finance the economy.

In addition, S\&P Global Ratings estimates that Tunisian banks will experience a significant negative effect on their financial profiles in 2020, namely on their profitability, as the country faces a recession linked to the COVID-19 pandemic and government containment measures. Fig. (3) presents the Interaction between NPL volatility and the ROA of 11 Tunisian banks before and after COVID-19. It shows that the level of banks' NPL is very volatile, which was already the case prior to COVID-19, and that the ROA is quite stable over this period. During the post-COVID-19 period, this figure shows volatility and a drop in the ROA of Tunisian banks, confirming the fact that COVID-19 has a negative impact on their profitability.

The IMF estimates that the Tunisian economy will contract by $4.3 \%$ in 2020 , followed by a weak recovery in 2021 . In our opinion, this will exacerbate the banks' asset quality problems and put further pressure on their already weak capitalization. In the absence of any regulatory forbearance measure, we believe that some Tunisian banks will be in 


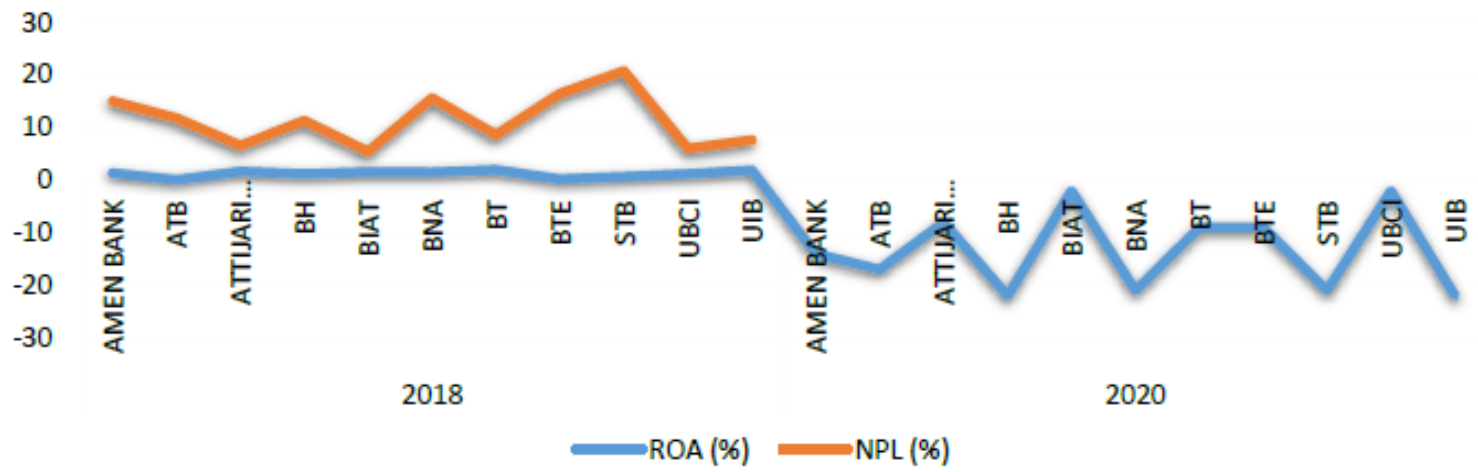

Fig. (3). Interaction between NPL volatility and the ROA of Tunisian banks before and after COVID-19. Source: Authors' calculations on the basis of the data provided by annual bank reports and by Tunisia Values (17 June 2020).

deficit in 2020, which will further worsen their already weak capitalization. If banks take charges in advance and fully fund existing and additional NPLs, it could wipe out half or two-thirds of total banking system equity (assuming an increase in NPLs to $19-22 \%$ of total loans). This would be equivalent to three to five years of profitability based on the operating profit before provisions of 2019 of the ten leading Tunisian banks. Indeed, the Tunisian authorities could push for the associated reforms and obtain the support of foreign donors, such as neighboring countries. For example, the World Bank has financed several financial reform programs in Egypt, including one in 2006 that specifically aimed to consolidate the banking system by reducing the number of institutions by nearly two-thirds and by merging two public banks.

The BCT introduced several measures to help banks deal with the effects of the crisis, including an automatic delay in debt service payments for retail customers and payment moratoriums for businesses. In our view, these measures do not remove credit risk from banks' balance sheets and will ultimately delay recognition of problematic assets. We therefore expect the cost of risk to increase slightly in 2020 and again in 2021, due to exposure to retail, tourism, some export industries and real estate. Tunisian bank's credit losses will soar.

Regulatory forbearance will allow banks to operate in the current environment and make arrangements at a slower pace. This approach was generally adopted by the Tunisian authorities during previous shocks (notably the tourism crisis in 2001). If banks take upstream costs and fully provision existing and additional NPLs, the result would be a large provisioning gap, which we estimate to be around half or two-thirds of total banking system capital. This would be equivalent to three to five years of profitability based on the operating income before provisions for 2019 of the top ten Tunisian banks. In addition, the banking system would need a significant increase in capitalization in the next 12-24 months, but we believe that the government and foreign shareholders do not have the appetite to inject additional capital. This is due to the government's limited latitude and the exit plans of a number of foreign shareholders.

While we believe that Tunisian banks will remain highly vulnerable to the deteriorating environment in the absence of such reforms, we do not see a significant failure risk of rated entities over the next 12 months. Some Tunisian banks have already been authorized to operate with negative equity in the past. The BCT is committed to injecting additional liquidity if necessary. In fact, it has injected nearly one billion Tunisian dinars (TND) (\$346 million) since the start of the COVID-19 pandemic. The financing profiles of Tunisian banks remain dominated by deposits and local financing instruments. The system's external debt - 15.5 billion Tunisian dinars as of November 30,2019 , i.e. $12 \%$ of the total liabilities of the system as of the same date - consists mainly of deposits from non-resident customers in convertible Tunisian dinars or in foreign currencies and of some lines from multilateral lending institutions (MLIs). The first generally belong to clients with economic interests in Tunisia (either offshore companies or Tunisian expatriates). We therefore do not expect volatility or significant capital outflows. MLI lines are generally covered by a parental guarantee (if the parent company is a foreign bank) or a final government guarantee (for lines granted to certain Tunisian public sector banks). Tunisian banks have never been active in international capital markets or attracted a significant volume of wholesale external financing. Some offshore companies are expected to use part of their Tunisian dinar deposits to cover local costs amid declining turnover.

\section{CONCLUSION}

In recent years, the Tunisian banking system has encountered considerable difficulties due to under-capitalization, poor asset quality and insufficient provisions made to cover the default risk. The rapid growth in the NPL level of Tunisian banks not only increases the vulnerability of these banks to possible shocks, but it also limits their lending operations with greater repercussions on economic activity. The purpose of this article is to study the factors that explain the volatility of NPLs in a time of crisis. The study focused on a sample of eighteen Tunisian banks observed during the period 2008-2018.

In the first part of our study, we examined the extent to which the volatility of NPLs by Tunisian banks could be explained by macroeconomic, governance, and bank-specific indicators. The use of the two dynamic approaches, DMMG and SMMG, shows that GDP growth and the inflation rate have a negative impact on banks' NPLs, while the real interest rate, the unemployment rate, the exchange rate, and corruption have a positive impact. It is now clear that the deterioration of the economic situation is at the heart of the volatil- 
ity of Tunisian banks' NPLs. As a result, banks need to actively monitor changes in macroeconomic risk factors by integrating stress tests into their risk management systems to ensure that they would remain resilient in the event of an extraordinary macroeconomic shock. Moreover, this analysis is also relevant for macroprudential policy, which can limit credit risk by acting on several of these variables. As for bank-specific variables, our results show that size and financing have a positive impact on the NPLs of Tunisian banks, while ROA and capital have a negative impact. The obtained results affirm that Tunisian banks should pay much more attention and importance to several factors when granting loans, in order to break the spiral of indebtedness and minimize the level of classified claims, in particular and the overall level of bad debts. To do this, and since the causes of these problems are multiple and are of a micro and macroeconomic nature, it is necessary to implement restructuring programs in the banking sector, especially in terms of governance, a set of measures aimed at consolidating banks' own funds and strengthening prudential rules.

By introducing the variable "Revolution" into our model, estimates show firstly that the liquidity risk has a positive and significant correlation with the NPLs of Tunisian banks, and secondly that the variable "revolution" presents a positive though not significant relationship with these. In the third section, we have tried to explore the feedback effects of the banking sector on the real economy. The results analysis of the impulse response functions show that the effect of the positive shock of the revolution on the NPL level is significant and negative; this effect records a recovery from the third year to stabilize at a negative equilibrium path. Although the impact of the revolution on the NPL level is insignificant, the management of deficiencies and financial regulation are essential for strengthening the financial system. The banking system must go back to a regulated mode of operation and recover its original functions. Restoring confidence in the system requires from regulatory or public authorities to take precise, clear and coordinated measures at the international level. It seems necessary to restore the banking system to its true mission, which is the financing of the real economy, and to adopt new rules allowing greater efficiency and better coordination of the supervisory bodies. The rapid implementation of this regulation is necessary to restore confidence to the various market players.

In the fourth section, we presented a descriptive study of the impact of the novel COVID-19 health crisis on the NPLs of Tunisian banks, since it is difficult today to measure this impact via econometric models given the few data available in Tunisian banks. We have shown that the COVID-19 crisis explains the volatility of the NPLs of Tunisian banks. Indeed, the latter are now facing a major problem, just as serious as the drop in net banking income and customer deposits: the significant weight of unpaid debts which will undermine their cash flow. In other words, the concern lies in the fact that the current health crisis, the duration of which it is difficult to predict, will affect the repayment capacity of customers, with the consequence of deteriorating the quality of loan portfolios as well as that of the profitability of Tunisian banks.
There are some forces that are conducive to solving NPLs. For example, the COVID-19 pandemic is not a crisis caused by the credit boom. If the economic downturn turns out to be temporary, many post-COVID-19 NPLs could be about viable illiquid businesses, rather than non-viable zombie businesses. Banks around the world have entered the COVID-19 pandemic with higher average capital ratios than during the 2008 crisis. The recently introduced IFRS 9 accounting standards may induce faster recognition of NPLs, and thus a resolution, thanks to their forward-looking nature (although a too rapid recognition of NPLs may also limit bank lending in times of recession).

Anticipation of future NPL levels is essential in formulating strategies for NPL resolution. It is tempting to use pre-crisis NPL levels to anchor these forecasts. Yet pre-crisis NPL levels are not a good indicator of post-crisis non-performing loan problems. After a crisis, NPLs increase up to three times their pre-crisis values on average, and more than ten times in extreme cases. It would then be necessary to be able to draw lessons from previous crises for the resolution of NPLs after COVID-19.

\section{CONFLICT OF INTEREST STATEMENT}

The authors declare that they have no conflict of interest.

\section{REFERENCES}

Abid L, Ouertani MN, Ghorbel S (2014). Macroeconomic and Bank Specific Determinants of Household's Non Performing Loans in Tunisia: A Dynamic Panel Data. Procedia Economics and Finance. 13.

Acclassato D, Ali Aga L, Eggoh J (2009). Microcrédit et corruption : Description et analyse théorique. http://www.lamicrofinance.org/files/26058_file_description.pdf

Agoraki EK, Delis MD, Pasiouras F (2011). Regulations, competition and bank risk-taking in transition countries. Journal of Financial Stability. 7: 38-48.

Ahlin C, Pang J (2008). Are financial development and corruption control substitutes in promoting growth? Journal of Development Economics. 86: 414-433.

Ahmad NH (2003). Credit Risk Determinants: By Institutional Type. Paper presented at the Proceedings of Malaysian Finance Association Conference.

Aiyar S, Bergthaler W, Garrido J, Ilyina A, Jobst A, Kang K, Kovtun D, Liu Y, Monaghan D, Moretti M (2015). A Strategy for Resolving Europe's Problem Loans. International Monetary Fund, European Department, Legal Department, and Monetary and Capital Markets Department.

Albulescu C (2020). Coronavirus and Oil Price Crash. Politehnica University of Timisoara, 13 Pages.

Anderson RC, Fraser DR (2000). Corporate Control, Bank Risk Taking, and the Health of the Banking Industry. Journal of Banking and Finance. 24: 1383-1398.

Anderson TW, Hsiao C (1981). Estimation of dynamic models with error components. Journal of the American Statistical Association. 76: 598-606.

Angelini P, Bofondi M, Zingales L (2017). The Origins of Italian NPLs. Working paper. June.

Anginer D, Cerutti E, Martínez Pería MS (2017). Foreign bank subsidiaries' default risk during the global crisis: What factors help insulate affiliates from their parents? Journal of Financial Intermediation. 29: 19-31.

Arellano M, Bond S (1991). Some tests of specification for panel data: Monte Carlo evidence and an application to employment equations. The Review of Economic Studies. 58(2): 277-297.

Arellano M, Bover O (1995). Another look at the instrumental variable estimation of error-components model. Journal of Econometrics. 68(1): 29-51. 
Asari F, Muhamad F, Ahmad NA, Latif W, Abdullah N, Jusoff K (2011). An Analysis of Nonperforming Loan, Interest Rate and Inflation Rate Using STATA Software. World Applied Sciences Journal. 12: 41-48.

Ashraf BN, Arshad S (2017). Foreign bank subsidiaries' risk-taking behavior: Impact of home and host country national culture. Research in International Business and Finance. 41: 318-335.

Baboucek I, Jancar M (2005). Effects of Macroeconomic Shocks to the Quality of the Aggregate Loan Portfolio. Working Papers 2005/01, Czech National Bank.

Bardhan S, Mukherjee V (2016). Bank-specific determinants of nonperforming assets of Indian banks. International Economics and Economic Policy. 13 (3): 483-498.

Barseghyan L (2010). Non-performing loans, prospective bailouts, and Japan's slowdown. Journal of Monetary Economics. 57 (7): 873890.

Beck R, Jakubik P, Piloiu A (2013). Non-performing loans: What matters in addition to the economic cycle?" Working Paper Series No. 1515. European Central Bank.

Beck T, Demirguc-Kunt A, Levine R (2005). SMEs, Growth, and Poverty: Cross-Country Evidence. Journal of Economic Growth. 10(3): 199229.

Belaid F (2014). Loan quality determinants: evaluating the contribution of bank-specific variables, macroeconomic factors and firm level information. IHEID Working Papers 04-2014, Economics Section, The Graduate Institute of International Studies.

Ben Gamra A (2020). Nouvelles dispositions prises dans le cadre de la lutte contre les conséquences économiques et sociales du COVID-19. Tunisie Numérique.

Berger A, De Young R (1997). Problem loans and cost efficiency in commercial banks. Journal of Banking and Finance. 21: 849-870.

Binder M, Hsiao C, Pesaran MH (2005). Estimation and inference in short panel vector autoregressions with unit roots and cointegration. Econometric Theory, 21(4):795-837.

Blundell R, Bond S (1998). Initial conditions and moment restrictions in dynamic panel data models. Journal of Econometrics. 87 (1): 115143.

Blundell R, Bond S (2000). GMM estimation with persistent panel data: An application to production functions. European Economic Review. 19: 321-340.

Bofondi M, Ropele T (2011). Macroeconomic determinants of bad loans: evidence from Italian banks. Occasional Papers. 8: 5-29.

Borio C, Furfine C, Lowe P (2001). Procyclicality of the financial system and financial stability: Issues and policy options. in: Marrying the macro- and micro-prudential dimensions of financial stability. BIS Papers, 1: 1-57.

Boudriga A, Taktak N, Jellouli S (2009). Bank specific, business and institutional environment determinants of non-performing loans: evidence from MENA countries. Paper presented at Economic Research Forum $16^{\text {th }}$ Annual Conference Cairo.

Bourbonnais R (2003). Econométrie. Editions Dunod. $5^{\text {th }}$ Edition. Paris.Gerard Grellet.

Boutbtane E, Coulibaly D, Rault C (2010). Immigration, growth and unemployment: Panel VAR evidence from OECD countries». Review of Labor Economics and Industrial Relations. 27(4): 399-420.

Brealey RA, Kaplanis EC (1996). The determination of foreign banking location. Journal of International Money and Finance. 15(4): 577597.

Bun JG, Windmeijer F (2010). The weak instrument problem of the system GMM estimator in dynamic panel data models. Econometrics Journal. 13: 95-126.

Bunn P, Redwood V (2003). Company Accounts-Based Modeling of Business Failures and the Implications for Financial Stability. SSRN Electronic Journal, December.

Caprio G, Klingebiel D (2003). Episodes of Systemic and Borderline Financial Crises. In: Klingebiel, D., Ed.,The World Bank, Washington DC.

Carstensen K, Hulsewig O, Wollmershauser T (2009). Monetary policy transmission and house prices: European cross-country evidence. CESifo Working Paper $\mathrm{N}^{\circ} 2750$.

Chaibi H, Ftiti Z (2015). Déterminants du risque de crédit: données probantes tirées d'une étude transnationale. Recherche en Commerce International et Finance. 33.

Chen M, Jeon BN, Wang R, Wu J (2015). Corruption and Bank RiskTaking: Evidence from Emerging Economies. Emerging Markets Review. 24: 122-148.
Dash M, Kabra G (2010). The determinants of non-performing assets in Indian commercial bank: An econometric study. Middle Eastern Finance and Economics. 7: 94-106.

De Bock R, Demyanets A (2012). Bank asset quality in emerging markets: determinants and spillovers. International Monetary Fund. Working Paper WP/12/71, 2012.

De Nicoló GD, Loukoianova E (2007). Bank ownership, market structure and risk. International Monetary Fund. IMF Working Paper No. $07 / 215$.

Dell'Ariccia G, Laeven L, Suarez G (2013). Bank leverage and monetary policies risk-taking channel; evidence from the United States. International Monetary Fund. IMF Working Paper No. 13/143.

Demirgüç-Kunt A, Detragiache E (1998). The determinants of banking crises: evidence from developing and developed countries. IMF Staff Papers. 45: 81-109.

Demirgüç-Kunt A, Detragiache E (2000). Monitoring banking sector fragility: a multivariate logit approach. World Bank Economic Review. 14(2): 287-307.

Dimitrios A, Helen L, Mike T (2016). Determinants of non-performing loans: Evidence from Euro-area countries. Finance Research Letters. Elsevier. 18(C): 116-119.

Djankov S, Shleifer A, McLiesh C (2007). Private Credit in 129 Countries. Journal of Financial Economics. 84(2: 299-329.

Drakos A, Kouretas A, Tsoumas C (2016). Ownership, interest rates and bank risk-taking in Central and Eastern European countries. International Review of Financial Analysis. 45: 308-319.

El Ansari F, Ben Abdallah M (2017). Les déterminants des prêts non performants : Etude empirique du secteur bancaire Marocain. Finance et Finance Internationale. 6.

Fernández de Lis F, Martínez Pagés J, Saurina J (2000). Credit Growth, Problem Loans and Credit Risk Provisioning in Spain. Working Papers from Banco de España, Working Papers Homepage No 18.

Figlewski S, Frydman H, Liang W (2012). Modeling the effect of macroeconomic factors on corporate default and credit rating transitions. International Review of Economic and Finance. 87-105.

Fofack H (2005). Nonperforming loans in Sub-Saharan Africa: causal analysis and macroeconomic implications. Policy Research Working Paper Series 3769, the World Bank.

Garcia-Marco T, Robles-Fernández M (2008). Risk-taking behavior and ownership in the banking industry: The Spanish evidence. Journal of Economics and Business. Elsevier. 60(4): 332-354.

Garsiya MT, Robles-Fernández M (2007). Risk-taking behavior and ownership in the banking industry: the Spanish evidence", J. Econ. Bus. . 60 (4), 332-354.

Glogowski A (2008). Macroeconomic determinants of polish banks' loan losses - Results of a panel data study. SSRN Scholarly Paper No. ID 1752913

Godlewski C (2004). Capital Regulation and Credit Risk Taking: Empirical Evidence from Banks in Emerging Market Economies. Finance Econ WPA 0409030. 1-27.

Godlewski C (2005). Bank capital and credit risk taking in emerging market economies. Journal of Banking Regulation. 6 (2): 128-145.

González-Hermosillo B (1999). Determinants of Ex-Ante Banking System Distress: A Macro-Micro Empirical Exploration of Some Recent Episodes. IMF Working Paper No. 99/33, 114 Pages.

Greenidge K, Grosvenor T (2010). Forecasting Non-performing Loans in Barbados. Journal of Business, Finance and Economics in Emerging Economies. 5(1): 80-107.

Hoggarth G, Logan A, Zicchino L M (2005). Macro stress tests of UK banks. BIS Papers 22: 392-408.

$\mathrm{Hu}$ JL, Li Y, Chiu YH (2004). Ownership and nonperforming loans: Evidence from Taiwan's banks. The Developing Economy. 42(3): 405 420 .

Hurlin C, Mignon V (2007). Une Synthèse des Tests de Racine Unitaire en sur Données de Panel. Economie et Prévision, 251-295.

Iannotta G, Nocera G, Sironi A (2007). Ownership Structure, Risk and Performance in the European Banking Industry. Journal of Banking and Finance. 31(7): 2127-2149.

Jakubík P, Reininger T (2013). Determinants of nonperforming loans in Central, Eastern and Southeastern Europe. Focus on European Economic Integration. 48-66.

Jappelli T, Pagano M (2002). Information Sharing, Lending and Defaults: Cross-Country Evidence. CSEF Working Papers from Centre for Studies in Economics and Finance (CSEF), University of Naples, Italy. 
Jimenez G, Saurina J (2006). Credit Cycles, Credit Risk, and Prudential Regulation. International Journal of Central Banking. 2(2).

Jovovic J (2014). Determinants of non-performing loans: econometric evidence based on 25 countries. Master thesis. City University London.

Kalemli-Ozcan S, Sorensen B, Villegas-Sanchez C, Volosovych V, Yesiltas $S$ (2015). How to construct nationally representative firm level data from the Orbis global database. Working Paper 21558. National Bureau of Economic Research.

Keeton WR (1999). Does Faster Loan Growth Lead to Higher Loan Losses? Federal Reserve Bank of Kansas City. Economic Review. Second Quarter.

Keeton WR, Morris C (1987). Why Do Banks' Loan Losses Differ? Federal Reserve Bank of Kansas City. Economic Review. 3-21.

Khemraj T, Pasha S (2009). The determinants of non-performing loans: an econometric case study of Guyana. MPRA Paper 53128, University Library of Munich, Germany.

Kirui S (2014). The effect of non-performing loans on profitability of commercial banks in Kenya. Master's Degree Thesis. University of Nairobi. Kenya.

Klein N (2013). Non-Performing Loans in CESEE: Determinants and Impact on Macroeconomic Performance. IMF working papers. 13(72): 1-27.

Koju L, Koju R, Wang S (2018). Macroeconomic and Bank-Specific Determinants of Non-Performing Loans: Evidence from Nepalese Banking System. Journal of Central Banking Theory and Practice. 3: $111-138$.

Kolapo TF, Ayendi RK, Oke MO (2012). Credit risk and commercial bank performance in Nigeria: panel model approach. Australian Journal of Business and Management Research. 2 (2): 31-38.

Kumar V, Kishore MP (2019). Macroeconomic and bank specific determinants of non-performing loans in UAE conventional bank. Journal of Banking and Finance Management. 2(1): 1-12.

Kwan SH, Eisenbeis RA (1995). Bank Risk, Capitalization and Inefficiency. Capitalization and Inefficiency. 96-35.

La Porta R, Lopez-de-Silanes F, Shleifer A, Vishny R (1997). Legal determinants of external finance. Journal of Finance. 52: 1131-1150.

La Porta R, Lopez-de-Silanes F, Shleifer A, Vishny R (1998). Law and finance. Journal of Political Economy. 106: 1113-1155.

Levine R (1996). Foreign Banks, Financial Development, and Economic Growth. Journal of Economic Literature. 35.

Liu X (2019). A Dynamic Model of Systemic Bank Runs. University of Hong Kong (HKU) - Finance Area, Faculty of Business and Economics, 42 Pages.

Louzis DP, Vouldis AT, Metaxas VL (2012). Macroeconomic and bankspecific determinants of non-performing loans in Greece: A comparative study of mortgage, business and consumer loan portfolios. Journal of Banking and Finance. 1012-1027.

Makri V, Tsagkanos A, Bellas A (2014). Determinants of non-performing loans: The case of Euro zone. Pano economicus. 61: 193-206.

Micco A, Panizza U, Yañez M (2004). Bank Ownership and Performance. SSRN Electronic Journal. December.

Mileris R (2012). Macroeconomic determinants of loan portfolio credit risk in banks. Inz. Ekon. 23 (5): 496-504.

Miller N, Peng L, Sklarz M (2011). House Price and Economic Growth. Journal of Real Estate Finance and Economics. 42(4): 522-541.

Nkusu M (2011). Nonperforming Loans and Macro financial vulnerabilities in Advanced Economies. IMF Working Paper 161.

Owojori AA, Akintoye RI, Adidu AF (2011). The challenge of risk management in Nigerian banks in the post consolidation era. Journal of Accounting and Taxation. 13 (2): 23-31.

Ozili K (2019). Non-Performing Loans and Financial Development: New Evidence. The Journal of Risk Finance. 20.

Pathan S (2009). Strong Boards, CEO Power and Bank Risk-Taking. Journal of Banking and Finance. 33: 1340-1350.
Pesaran HH, Shin Y (1998). Generalized impulse response analysis in linear multivariate models. Economics Letters. 58: 17-29.

Quagliarello M (2007). Banks' Riskiness Over the Business Cycle: a Panel Analysis on Italian Intermediaries Applied Financial Economics 17: $119-138$

Rachman RA, Kadarusman YB, Anggriono K, Setiadi R (2018). Bankspecific factors affecting non-performing loans in developing countries: case study of Indonesia. The Journal of Asian Finance, Economics and Business. 5(2): 35-42.

Radivojević N, Cvijanović D, Sekulic D, Pavlovic D, Jovic S, Maksimović $G$ (2019). Econometric model of non-performing loans determinants. Physica A 520. 481-488.

Radivojevic N, Jovovic J (2017). Examining of determinants of nonperforming loans. Prague Econ. Pap. 26 (3): 300-316.

Rajan MS (1994). International and Area Studies in India. Fiirst Published April 1, 1994 International Studies 31 (2).

Rajan R, Dahl SC (2003). Non-performing loans and terms of credit of public sector banks in India: an empirical assessment. Occasional Papers. Reserve Bank of India. 24 (3).

Reinhart C, Rogoff K (2010). From Financial Crash to Debt Crisis. NBER Working Paper 15795.

Repullo R (2004). Capital requirements, market power, and risk-taking in banking. Journal of Financial Intermediation. 13(2): 156-182.

Rinaldi L, Sanchis-Arellano A (2006). Household debt sustainability: what explains household non-performing loans? An Empirical Analysis. ECB Working Paper.

Salas V, Saurina J (2002). Credit risk in two institutional regimes: Spanish commercial and savings banks. Journal of Financial Services Research. 22: 203-224.

Saurina G, Jiménez G (2006). Credit cycles, credit risk, and prudential regulation. Documentos de trabajo del Banco de Espana. 31: 9-34.

Seuraj S, Watson PK (2012). Banking Regulation: does compliance pay? Evidence from Trinidad et Tobago. Social and Economic Studies. 61(4).

Shu C (2002). The Impact of macroeconomic environment on the asset quality of Hong Kong's banking sector. Hong Kong Monetary Authority Research Memorandums.

Sigmund M, Ferstl R (2019). Panel vector autoregression in R with the package panelvar. The Quarterly Review of Economics and Finance. https://doi.org/10.1016/j.qref.2019.01.001.

Sinkey Jr JF, Greenawalt MB (1991). Loan-loss Experience and Risk-taking Behavior at Large Commercial Banks. Journal of Financial Services Research. 5(1): 43-59.

Skarica B (2014). Determinants of non-performing loans in Central and Eastern European countries. Finance: Theory and Practice. 38: 3759.

Skrabic Peric B, Smiljanic AR, Aljinovic Z (2018). Credit risk of subsidiaries of foreign banks in CEE countries: Impacts of the parent bank and home country economic environment. North American Journal of Economics and finance. https://doi.org/10.1016/j.najef.2018.03.009

Tanasković S, Jandrić M (2015). Macroeconomic and institutional determinants of non-performing loans. Journal of Central Banking Theory and Practice. 4(1): 47-62.

Vardar G, Özgüler I (2015). Short Term and Long Term Linkages among Nonperforming Loans, Macroeconomic and Bank- Specific Factors: An Empirical Analysis for Turkey. Ege Academic Review. 313-325.

Weill L (2009). Do Islamic Banks Have Greater Market Power?" Working Papers of LaRGE Research Center 2009-02, Laboratoire de Recherche en Gestion et Economie (LaRGE), Université de Strasbourg.

Zeng S (2012). Bank Non-Performing Loans (NPLS): A Dynamic Model and Analysis in China. Modern Economy. 100-110. 